\title{
Diel periodicity and chronology of upstream migration in yellowphase American Eels (Anguilla rostrata)
}

Joni L. Aldinger

Follow this and additional works at: https://researchrepository.wvu.edu/etd

\section{Recommended Citation}

Aldinger, Joni L., "Diel periodicity and chronology of upstream migration in yellowphase American Eels (Anguilla rostrata)" (2015). Graduate Theses, Dissertations, and Problem Reports. 5054.

https://researchrepository.wvu.edu/etd/5054

This Thesis is protected by copyright and/or related rights. It has been brought to you by the The Research Repository @ WVU with permission from the rights-holder(s). You are free to use this Thesis in any way that is permitted by the copyright and related rights legislation that applies to your use. For other uses you must obtain permission from the rights-holder(s) directly, unless additional rights are indicated by a Creative Commons license in the record and/ or on the work itself. This Thesis has been accepted for inclusion in WVU Graduate Theses, Dissertations, and Problem Reports collection by an authorized administrator of The Research Repository @ WVU. For more information, please contact researchrepository@mail.wvu.edu. 


\title{
Diel periodicity and chronology of upstream migration in yellow- phase American Eels (Anguilla rostrata)
}

\author{
Joni L. Aldinger \\ Thesis submitted \\ to the Davis College of Agriculture, Natural Resources, and Design \\ at West Virginia University \\ in partial fulfillment of the requirements for the degree of \\ Master of Science in \\ Wildlife and Fisheries Resources
}

Stuart A. Welsh, Ph.D., Chair

George T. Merovich, Ph.D.

Daniel A. Cincotta, M.S.

School of Natural Resources

Morgantown, WV

2015

Keywords: American eel (Anguilla rostrata), yellow-phase, upstream migration, periodicity Copyright 2015 Joni L. Aldinger 


\title{
ABSTRACT \\ Diel periodicity and chronology of upstream migration in yellow- phase American Eels (Anguilla rostrata)
}

\author{
Joni L. Aldinger
}

This thesis examined 24-h diel periodicity of upstream migration of yellow-phase American Eels (Anguilla rostrata), and the chronology of upstream movements within diel periods (day, night, and twilight). Further, relationships were examined for total lengths of upstream migrants and diel movements (vespertine, nocturnal, matutinal, and diurnal), as well as for total lengths and season of year. The thesis is comprised of two chapters: (1) an introduction and literature review on American Eel life history, migration and movement, and population concerns, and (2) a research study of diel periodicity and movement chronology of upstream migrant yellow-phase American Eels at an eel ladder. Study objectives were to (1) examine diel periodicity of upstream migrants using time-series spectral analysis, (2) describe the distribution of passage counts during diel periods (day, twilight, and night) among seasons (spring, summer, and fall), and (3) examine size of upstream migrants relative to diel and seasonal periods. Data were collected at the Millville Dam eel ladder on the lower Shenandoah River, West Virginia, from 2011-2014. Six multi-day passage events with a high number of passage counts were selected for analysis and categorized by season (spring, summer, late summer/early fall, fall) and diel periods of movement (vespertine, nocturnal, matutinal, and diurnal). To examine diel periodicity of movements, I graphically-depicted passage count data as time-series histograms (10-min bins) and used time-series spectral analysis (Fast Fourier Transformation, FFT) to identify cyclical patterns and periodicity of upstream migration. I also pooled histogram data into 14-h periods (18:00-08:00 hours) using 10-min bins for each multi-day passage event (representing vespertine, nocturnal, and matutinal movements). Using pooled 14-h histograms, I examined patterns of movements for each passage event and described multiple peaks of passage counts for vespertine, nocturnal, and matutinal movements by fitting a normal model and eight normal mixture models (2-9 mixtures). The Bayesian information criterion (BIC) was used to select the best approximating model. A mixed-model methodology was used to examine relationships among total length (TL), diel period, and season. Periodicity of movements closely followed a 24-h cycle of activity with most movement being nocturnal. Based on mixture model analysis, multimodal models were supported by the data, but distribution patterns and timing of upstream migration were complex and variable across the six passage events. An additive-effects model of diel period + season was selected as the best approximating model for the mixed-model analysis of TL. Also, the mean TL of individuals using the eel ladder decreased as the night progressed (i.e., from vespertine to diurnal periods of movement) and was the highest during fall $(330.3 \mathrm{~mm} \pm 1.9 \mathrm{SE}, \mathrm{n}=472)$ relative to similar mean values of TL for spring $(304.1 \mathrm{~mm} \pm 1.0$ $\mathrm{SE}, \mathrm{n}=1700)$, summer $(301.2 \mathrm{~mm} \pm 1.1 \mathrm{SE}, \mathrm{n}=1548)$ and late summer/early fall $(303.4 \mathrm{~mm} \pm$ $0.87 \mathrm{SE}, \mathrm{n}=2269$ ). This study provided new insights into the upstream migration ecology of yellow-phase American Eels and an increased understanding of dam passage at the Millville Dam eel ladder. 


\section{Acknowledgments}

I would like to thank my graduate committee for their contributions both to this project and my various learning experiences throughout the past two years, especially Dr. Stuart Welsh, my advisor and committee chair, for his guidance and support and for giving me this opportunity and allowing me to be a part of this research project. Thank you to Dr. George Merovich for helping me better understand and appreciate statistics and for assistance examining my study data. I would like to thank Dan Cincotta for sharing his knowledge, for sparking my interest in ichthyology, and for making the fish job possible that launched my career in this field.

I would also like to thank PE Hydro Generation, LLC, and the West Virginia Division of Natural Resources for funding this project as well as the West Virginia Cooperative Fish and Wildlife Research Unit for their support. A special thank you to Becky Nestor for all her assistance and support and for always being there with a smile and words of wisdom.

I would like to thank my fellow Welsh lab students Corbin Hilling, Austin Rizzo, Dustin Smith, Nate Taylor, and Patricia Thompson who assisted me in the field and lab and made our lab such an enjoyable place to be a part of.

Finally, I would like to thank my family and friends for their support and encouragement these past two years. A special thank you to my father who has always believed in me and instilled in me an appreciation and curiosity for nature at an early age. And thank you to my husband, Kyle, for his emotional support, for always offering to help in any way that he could without hesitation, and for inspiring me and sharing my love of nature. 


\section{Table of Contents}

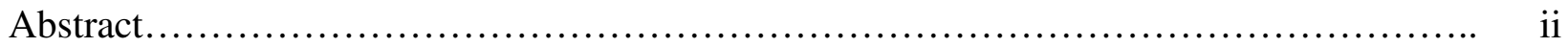

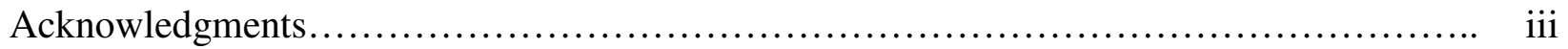

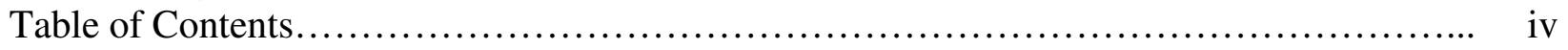

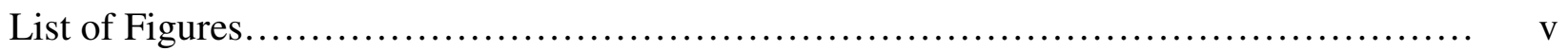

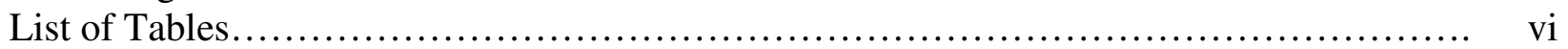

Chapter 1. Literature Review..................................................... 1

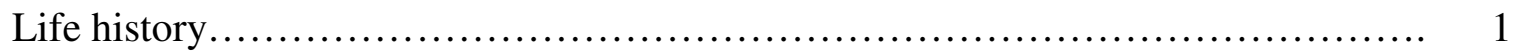

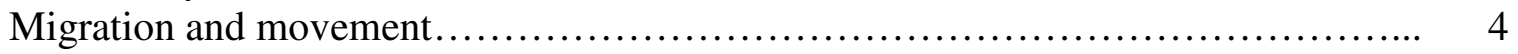

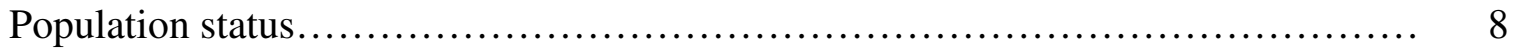

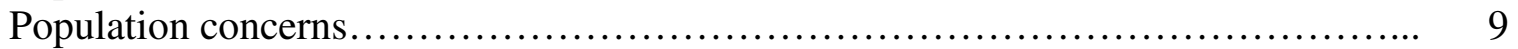

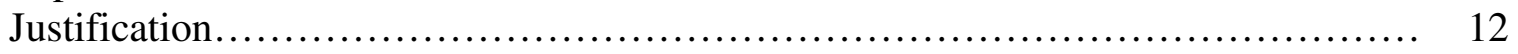

Literature Cited.............................................................. 13

Chapter 2. Diel periodicity and chronology of upstream migration in yellow-phase

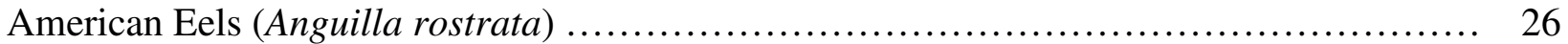

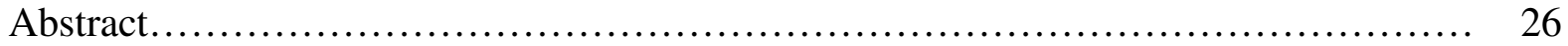

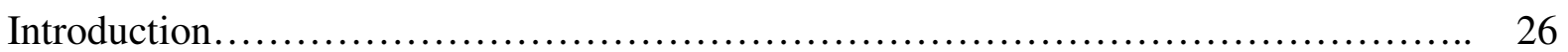

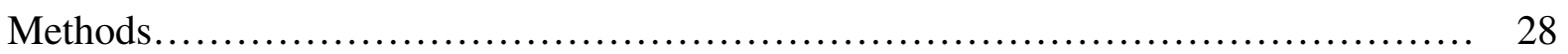

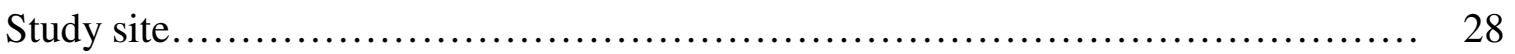

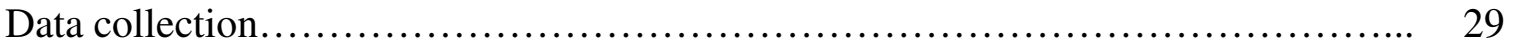

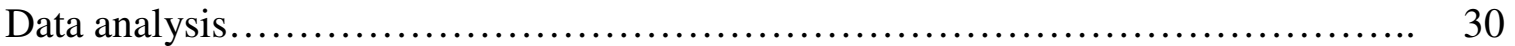

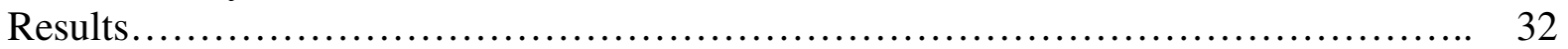

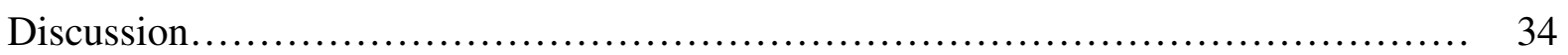

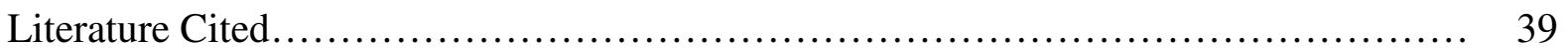

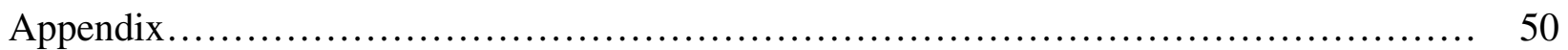




\section{List of Figures}

Figure 2.1. Frequency of counts of American Eels passing through the eel ladder and river discharge $\left(\mathrm{m}^{3} / \mathrm{s}\right)$ at the Millville Dam using 10-min bins (starting at 12:00 on the first day of the period) for six periods: 17-28 May 2012 (A, B), 12-21 July 2013 (C, D), 22 July-3 August 2014 (E, F), 13 September-1 October 2011 (G, H), 18-27 September 2012 (I, J), and 14-21 October 2014 (K, L). Seasons are labeled as spring (SP), summer (SM), late summer/early fall (SF), and fall (FL). A reference line indicates the dominant frequency.......

Figure 2.2. Frequency of counts of American Eels passing through the Millville Dam eel ladder on the Shenandoah River pooled into a 14-h period (starting at 18:00) using 10-min bins for six periods: 17-28 May 2012 (A), 12-21 July 2013 (B), 22 July-3 August 2014 (C), 13 September-1 October 2011 (D), 18-27 September 2012 (E), and 14-21 October 2014 (F). The lighter shaded areas represent twilight periods (vespertine and matutinal movements) and the dark shaded area represents night (nocturnal movements). Seasons are labeled as spring (SP), summer (SM), late summer/early fall (SF), and fall (FL)....................

Figure 2.3. Descriptive statistics of TL ( $\mathrm{mm}$ ) of American Eels using the Millville Dam eel ladder during four diel periods of movement (vespertine $=\mathrm{V}$, nocturnal $=\mathrm{N}$, matutinal $=\mathrm{M}$, and diurnal=D). Means for each period are represented with a bolded line, boxes indicate $25 \%$ and $75 \%$ quantiles, and tails indicate $95 \%$ confidence intervals. Points indicate outliers

Figure 2.4. Descriptive statistics of TL (mm) of American Eels using the Millville Dam eel ladder during four seasonal periods ( spring=SP, summer=SM, late summer/early fall=SF, and fall=FL). Means for each season are represented with a bolded line, boxes indicate $25 \%$ and $75 \%$ quantiles, and tails indicate $95 \%$ confidence intervals. Points indicate outliers.........

Figure 2.5. Descriptive statistics of TL (mm) of American Eels using the Millville Dam eel ladder during four diel periods of movement (vespertine $=\mathrm{V}$, nocturnal $=\mathrm{N}$, matutinal $=\mathrm{M}$, and diurnal=D) for spring (A), summer (B), late summer/early fall (C), and fall (D). Means for each season are represented with a bolded line, boxes indicate $25 \%$ and $75 \%$ quantiles, and tails indicate $95 \%$ confidence intervals. Points indicate outliers

Figure 2.6. Relationship between log TL of American Eels passing through the eel ladder and $\log$ river discharge $\left(\mathrm{m}^{3} / \mathrm{s}\right)$ at the Millville Dam on the Shenandoah River.................

Figure 2.7. Relationship between log TL of American Eels passing through the eel ladder and lunar illumination at the Millville Dam on the Shenandoah River. 


\section{List of Tables}

Table 2.1. Model selection statistics (BIC values) for mixture models used to describe the number of modal peaks of American Eel passage at the Millville Dam eel ladder during periods of twilight and night. Models were fit to histograms of the number of individuals passing through the eel ladder pooled into a 14-h period (starting at 18:00 hours, with 10min bins) for each multi-day passage event. The BIC values in bold print represent the best approximating model for each passage event.......................................................................... 


\section{Chapter 1: Literature Review}

This thesis focuses on the diel periodicity, timing, and lengths of upstream migrant yellow-phase American Eels (Anguilla rostrata) and includes two chapters. The first chapter reviews American Eel ecology and consists of information on life history, upstream migration, population concerns, and dams and eel ladders. The second chapter is a research study on the diel periodicity of upstream migration of yellow-phase American Eels at the Millville Dam eel ladder on the Shenandoah River, WV.

\section{Ecology}

\section{Life History}

The American Eel (Anguilla rostrata) is a catadromous species with a complex life history. It has a vast geographical distribution, ranging from Greenland to Venezuela (Tesch 1977; Facey and Van Den Avyle 1987; Oliveira 1999). The species occupies a variety of habitat types, including ponds, lakes, streams, rivers, marshes and estuaries (Tesch 1977; Fahay 1978; Helfman et al. 1984; Van Den Avyle 1984; Facey \& Van Den Avyle 1987; Jessop 2010). It has also been observed in a variety of microhabitats, such as leafy, mud bottoms and undercut banks, coarse gravel and cobble, and sandy substrates (Tesch 1977; Meffe and Sheldon 1988; Strickland 2002). Given its large geographic range and ability to thrive in freshwater and saltwater habitats, the American Eel is considered a highly adaptive species.

There are five major life stages of the American Eel during which biological changes occur: leptocephalus, glass, elver, yellow and silver (Oliveira 1999). American Eels spawn in the Sargasso Sea primarily from February to April (Schmidt 1923; Helfman et al. 1987; Oliveira 1999; Powles and Warlen 2002), relative to European Eels that spawn there from March into June (McCleave and Kleckner 1987; McCleave et al. 1987). After hatching, ribbon-shaped 
leptocephalus larvae are carried by Gulf Stream ocean currents for up to a year and dispersed along the North American continental shelf (Kleckner and McCleave 1985; Castonguay and McCleave 1987). Upon entering coastal areas, they metamorphose into "glass eels," characterized by transparent, snake-like bodies (Kleckner and McCleave 1985; Castonguay and McCleave 1987; McCleave et al. 1987). During winter and spring, glass eels move into estuaries where they become pigmented and transition to elvers (Facey and Van Den Avyle 1987; McCleave and Wippelhauser 1987; Dutil et al. 2009). Elvers may migrate to freshwater or remain in tidal rivers and estuaries (Facey and Van Den Avyle 1987; Helfman et al. 1987). As the elvers make their way upstream and grow larger $(>150 \mathrm{~mm})$, their pigment changes to a yellow-green, and they transition to the yellow phase, the dominant growth phase and longest life stage (Fahay 1978; Facey and Van Den Avyle 1987; ASMFC 2000; Beak 2001).

Yellow-phase eels are considered sexually immature adults. Gender differences are present although not externally evident (ASMFC 2000). Sex can be determined by examining gonadal tissues (Dolan and Power 1977; Facey and LaBar 1981). Sex determination may be influenced by environmental factors, such as population densities (Helfman et al. 1987; Krueger and Oliveira 1999). High density areas are mainly occupied by males while low-density areas are predominantly female (Krueger and Oliveira 1999). During the yellow phase, eels inhabit estuaries or migrate long distances upstream where they spend as many as 30 years feeding and growing to maturity before migrating downstream (Tesch 1977; Helfman et al. 1987; Jessop 1987; McCleave et al. 1987; Smogor et al. 1995). Males are typically found in estuaries and lower river systems while females tend to occupy the upper portions of watersheds (Helfman et al. 1987). The growth rate, size, and life span of males are typically less than that of females (Helfman et al. 1984; Krueger and Oliveira 1997; Oliveira 1997; Powles and Warlen 2002). 
Males mature and migrate downstream at a smaller size and earlier age than females. The lengthy, slow growth of females maximizes size and increases fecundity (Helfman et al. 1987). Several studies have found that growth rates of males and females vary depending on latitude (Helfman et al. 1987; Oliveira 1999; Oliveira and McCleave 2002; Jessop 2010). Eels in the northern region of their range remain in freshwater systems longer and reach larger sizes before migrating back to the Sargasso Sea than do eels in the southern region (Helfman et al. 1987). In some cases, yellow-phase eels begin downstream migration before transitioning to the silver phase (Kleckner et al. 1983).

During the final stage, the silver phase, American Eels reach sexual maturity and undergo morphological and physiological changes that equip them for their seaward migration (McCleave et al. 1987; Oliveira 1999; ASMFC 2000). These changes include the silver pigment that gives the phase its name (Krueger and Oliveira 1999), increased eye diameter which may enhance vision in deep water (ASMFC 2000; Cottrill et al. 2002), enlarged pectoral fins which may increase swimming capacity (Durif et al. 2003; McGrath et al. 2003), an increased number of swim bladder blood vessels that may enhance buoyancy control (ASMFC 2000), and lateral line development (Zacchei and Tavolaro 1988). The eels also stop feeding, and the digestive tract degenerates (Pankhurst and Sorensen 1984; Durif et al. 2003). Downstream migration to the Sargasso Sea typically occurs from September to December (Able and Fahay 1998; Krueger and Oliveira 1999). Several studies have found downstream migration to be associated with environmental factors including water temperature, stream flow, precipitation, turbidity, lunar phase, and incident light (Lowe 1952; Winn et al. 1975; Tesch 1977; Vøllestad et al. 1986; Bergersen and Klemetsen 1988; Euston et al. 1997; Hammond and Welsh 2009; Eyler 2014). Olfaction has also been associated with downstream migration from estuary to ocean (Barbin et 
al. 1998; Haro 2003). Spawning occurs during late winter through early spring in the Sargasso Sea (Oliveira 1999; Powles and Warlen 2002). Although spawning behavior has not been observed, American Eels are presumed to spawn panmictically before dying (McCleave et al. 1987; Oliveira 1999; ASMFC 2000). The exact spawning location is unknown; however, based on the collection of leptocephalus larvae, researchers hypothesize that spawning occurs in the southern region of the Sargasso Sea, on the warm side of thermal fronts, in the upper 500-m section of the water column (Kleckner et al. 1983; Kleckner and McCleave 1985; McCleave et al. 1987). While the ages of silver-phase American Eels vary, length ranges are similar among sexes, with males being smaller than females (Helfman et al. 1987; Oliveira 1999). Studies have also found the size of mature females and the age of mature males to be positively correlated with latitude (Helfman et al. 1987; Oliveira 1999; Jessop 2010).

\section{Migration and Movement}

A key component of the American Eel's yellow phase is migration and movement, which is influenced by several variables, including time of year and night as well as water temperature (Walsh et al. 1983; ASMFC 2000; Hammond and Welsh 2009). Migration occurs primarily during night and twilight, but movements have been observed during the day (McGrath et al. 2003; Verdon et al. 2003; Welsh and Aldinger 2014). In many freshwater systems including the Potomac River drainage, yellow-phase eels migrate upstream from spring through fall (Richkus and Whalen 2000; Hammond and Welsh 2009; Welsh \& Liller 2013). The start and termination of annual upstream migration is controlled partly by seasonal water temperature changes. In the spring, upstream movements of immature eels are associated with water temperatures between 10 and $16^{\circ} \mathrm{C}$ (Smith and Saunders 1955; Sorensen and Bianchini 1986; EPRI 1999; Jessop 2003; Schmidt et al. 2009; Welsh et al. 2015). Hammond \& Welsh (2009) determined that upstream 
migration during spring was associated with water temperature and stream flow, and spring temperatures exceeding $15^{\circ} \mathrm{C}$ necessitate upstream eel passage at hydroelectric facilities. They also found that downstream movements during fall coincided with decreasing water temperatures (Hammond and Welsh 2009). When water temperatures fall below $10^{\circ} \mathrm{C}$, juvenile American Eels become torpid (Walsh et al. 1983). In the lower Shenandoah River drainage of the Potomac River system, eels overwintered near tributary mouths in thermal refuge areas (Hammond and Welsh 2009).

Other environmental cues can influence migration including olfaction, lunar phase, stream flow, and precipitation (Lowe 1952; Walsh et al. 1983; Sorensen and Bianchini 1986; Barbin 1998; Cairns and Hooley 2003; McGrath et al. 2003; Hammond \& Welsh 2009; Welsh \& Liller 2013). Olfactory cues may be used for orientation, especially to locate home sites and identify appropriate transport tides in estuaries (McCleave and Wippelhauser 1987; Barbin 1998). American Eel migration and localized movements seem to be influenced by lunar phase as well. Eels tend to avoid ambient light, and movements increase during new moon phases when lunar illumination is minimal and nights are darkest (Lowe 1952; Winn et al. 1975; Lamothe et al. 2000; Cairns and Hooley 2003; Hammond \& Welsh 2009; Welsh and Liller 2013; Welsh et al. 2015). Fluctuations in stream flow and sudden changes caused by precipitation may cue upstream migration (Durif et al. 2003; Verdon et al. 2003; Hammond and Welsh 2009; Welsh and Liller 2013). Water temperature, stream flow, and lunar phase have been correlated with migration in the Shenandoah River drainage of the upper watershed of the Potomac River system, and similar results have been found along the east coast (Lowe 1952; Tesch 1977; Cairns and Hooley 2003; Hammond and Welsh 2009; Schmidt et al. 2009; Welsh and Liller 2013). Welsh and Liller (2013) and Welsh et al. (2015) found that upstream migration of yellow-phase 
eels in the lower Shenandoah River was associated with increased river discharge as well as lowlight new moon phases. Welsh and Liller (2013) considered that an increase in water volume may offer less constrained travel and provide access to additional migration routes and habitat or, possibly, that increased turbidity associated with high river discharge provides reduced-light conditions favorable for migration. Also, considering the American Eel's nocturnal behavior and avoidance of ambient light, cloud cover may influence upstream migration (Lowe 1952; Cairns and Hooley 2003; Schmidt et al. 2009; Welsh and Liller 2013).

Evaluating the impacts of environmental factors on upstream migration in freshwater systems is difficult, because the abundance of eels decreases as the distance upstream increases (Wiley et al. 2004; Laffaille et al. 2005). Much of the research investigating environmental influences of migration was conducted in estuarine systems (Dutil et al. 1988; Martin 1995; Parker and McCleave 1997; Jessop 2003). In addition to the variables previously discussed, water chemistry, barometric pressure, air temperature, and sunlight may affect upstream migration (Miles 1968; Sorensen and Bianchini 1986; Euston et al. 1997). Migration can also be affected directly and indirectly by obstacles such as dams, which may prevent eels from reaching habitat upstream or cause mortality by turbines as they migrate downstream (McCleave 2001; Verdon and Desrochers 2003; Verreault et al. 2004).

In addition to long-range migration, yellow-phase eels have displayed homing behavior and established home ranges (Bianchini et al. 1982; Parker 1995; Oliveira 1997; Lamothe et al. 2000). In estuaries, tidal stages affect localized movements (Dutil et al. 1988; Parker 1995).

Short-range movements upstream and downstream have been observed during summer months at dusk and dawn (Gunning and Shoop 1962; Ford and Mercer 1986; Oliveira 1997; Hammond and Welsh 2009). American Eels often use cover during daylight and move near dusk and dawn and 
throughout the night, suggesting crepuscular or nocturnal foraging (Sorensen et al. 1986; Meffe and Sheldon 1988; Hammond and Welsh 2009). These local movements may be affected by food and habitat availability as well as eel abundance and intraspecific competition (Ford and Mercer 1986; Helfman 1986; Wiley et al. 2004).

American Eels tend to avoid ambient light, and several studies have observed movement peaks occurring near dusk and dawn and around midnight, suggesting a pattern of nocturnal movement rather than migration occurring during all hours of the night (Helfman 1986; Sorensen et al. 1986; Dutil et al.1988; Parker 1995; McGrath et al. 2003; Verdon et al. 2003; Hammond and Welsh 2009; Schmidt et al. 2009; Welsh and Aldinger 2014). Behavioral diel periodicity has been documented in other fishes, especially in the spawning behaviors of reef fishes and sciaenids (Lobel 1978; Locascio and Mann 2008). Lobel (1978) repeatedly observed reef fishes courting and spawning one hour before sunset during the evenings of the week prior to a full moon throughout their spawning seasons. These species include angelfish (Centropyge potteri), butterflyfishes (Chaetodon fremblii, C. multicinctus, and C. unimaculatus), goatfish (Parupeneus multifasciatus), and surgeonfishes (Acanthurus nigroris, Ctenochaetus strigosus, Zebrasoma flavescens). Several studies have also found that spawning-related choruses produced by sciaenid species occur from dusk to several hours after nightfall, usually ceasing or dramatically declining by 0000-0300 hours (Fish and Cummings 1972; Takemura et al. 1978; Mok and Gilmore 1983; Holt et al. 1985; Saucier and Baltz 1993; Connaughton and Taylor 1995; Locascio and Mann 2008). Few studies, however, have researched diel periodicity of movement in fishes, and while several studies have examined different aspects of the American Eel's yellow phase including migration and diel activity, few have considered a temporal component, necessitating future research to examine the relationship between movement and time of night. 


\section{Population Status}

American Eel abundance has decreased considerably throughout its range since the early 1980s (ASMFC 2000; COSEWIC 2006; MacGregor et al. 2008). Because of its vast distribution, the extent of global population decline is unknown, but regional declines in numbers and juvenile recruitment, like those documented in the St. Lawrence River, have been used as indicators (Oliveira 1999; Richkus and Whalen 2000; COSEWIC 2006; Cairns et al. 2008; de Lafontaine 2009). Studies on the Upper St. Lawrence River have indicated that while the number of eels using ladders has declined in recent decades, the size of eels migrating upstream has increased significantly, possibly due to decreased recruitment (Casselman 2003; McGrath et al. 2003; de LaFontaine et al. 2009; Marcogliese \& Casselman 2009). Harvest data from the Atlantic coastal states also indicates a dramatic decline in recent decades (ASMFC 2013). Harvest landings peaked at 1,792,568 kg in 1979 and hit a low of 290,854 kg in 2002. Several environmental and anthropogenic factors may be contributing to declines (Castonguay et al. 1994a; 1994b; Haro et al. 2000; McCleave 2001; Neraas and Spruell 2001; Casselman 2003; Verreault et al. 2004; Wiley et al. 2004; COSEWIC 2006; Clark 2009; ASMFC 2013).

Concern for the American Eel is increasing as the population continues to decline. In response to the decline, the Atlantic States Marine Fisheries Commission (ASMFC) created an interstate fishery management plan in 2000 to conserve and protect the species while providing sustainable fisheries (ASMFC 2000). In April 2006, the Committee on the Status of Endangered Wildlife in Canada (COSEWIC) designated the American Eel as a species of "special concern" due to its population decline, especially in the upper St. Lawrence River (COSEWIC 2006). Declines in harvest landings have prompted two petitions to list the American Eel as "threatened" or "endangered" under the Endangered Species Act (ESA). Upon completing a 12- 
month status review, the U.S. Fish and Wildlife Service (USFWS) and the National Marine Fisheries Service (NMFS) determined in 2007 that listing the species was not warranted at that time, finding that declines in some areas had not put the total population in danger of extinction (50 CFR 17 2007). The review considered the eel's vast range, adaptability of different habitat types and aquatic systems, habitat availability, stable recruitment, and also that the population still contained millions of individuals. In April 2010, the American Eel was petitioned again for listing under the ESA by the Center for Environmental Science, Accuracy, and Reliability (CESAR, formerly the Council for Endangered Species Act Reliability), resulting in another status review (50 CFR 17 2011). The USFWS is currently conducting the status review and must submit a finding to the Federal Register by September 30, 2015.

\section{Population Concerns}

While the exact cause of decline remains unknown, potential factors include oceanic and climatic changes (Castonguay et al. 1994b; Haro et al. 2000), chemical contamination and pollution (Castonguay et al. 1994a), overharvest (Casselman 2003; Clark 2009; ASMFC 2013), and habitat loss (Wiley et al. 2004), as well as migration barriers and hydroelectric impacts (McCleave 2001; Neraas and Spruell 2001; Verreault et al. 2004; COSEWIC 2006). The parasite Anguillacoloides crassus also may contribute to the species' population decline (Haro et al. 2000). The nematode damages the eel's swim bladder, reducing swimming performance and potentially reducing growth, which can impact a yellow-phase eel's ability to migrate upstream or prevent a silver-phase eel from completing its spawning migration to the Sargasso Sea (Barse et al. 2001; Kirk 2003; Kennedy 2007; Palstra et al. 2007; Zimmerman and Welsh 2012).

Climatic changes and chemical contamination are environmental factors that could greatly impact the American Eel population and should be considered in conservation. Oceanic 
changes, including changes in currents and temperature, could impact the development and success of leptocephalus larvae (Knights 2003). Currents slowing oceanic migration can increase starvation and predation of larvae. Unfavorable currents may affect the passive drifting of larvae and reduce their dispersal along the Atlantic coast and also influence glass eel recruitment along the continental shelf. Knights (2003) suggested that warming of the Sargasso Sea/Sub-Tropical Gyre spawning area may also increase starvation of leptocephalus larvae by inhibiting spring mixing of the thermocline, which impedes nutrient circulation and decreases productivity. Water contamination and chemical pollution could also potentially affect the eel's migratory and breeding success by disrupting migratory behavior, reducing reproductive ability, and increasing mortality (Robinet and Feunteun 2002). The American Eel's long lifespan and high fat content put it at a greater risk of exposure to and bioaccumulation of contaminants and xenobiotics including polychlorinated biphenyl (PCBs), mirex, and mercury. As the eel migrates seaward and stops feeding, lipid stores that contain the contaminants are used for energy. This problematically releases the pollutants back into circulation, concentrating in the eel's gonads during the critical time of gametogenesis. Robinet and Feunteun (2002) suggest that, based on toxicological analysis, the condition of individuals migrating to spawn is a limiting factor of spawning success. Because of the high levels of contaminant absorption, some states have issued consumption advisories for the American Eel.

Overfishing of eels at different phases of their life cycle may also be significantly affecting population decline (ASMFC 2013). Although today's American Eel fisheries are only a fraction of what they have been historically, they are still a valuable resource commercially and recreationally. Glass eels, considered a delicacy in Asia, are in high demand, but most coastal states have restricted or banned glass eel harvest (ASMFC 2013). In 2012, only Maine and South 
Carolina permitted commercial harvest of glass eels. The landings totaled 10,077 kg and were valued at almost $\$ 40$ million, which is 20 times greater than the past 11 years' average value, according to the ASMFC (ASMFC 2012, 2013). Yellow- and silver-phase eels are also commonly harvested. The ASMFC fishery management plan created in 2000 suggested that heavy harvest may contribute to population decline because of the American Eel's slow maturation rate, glass eels' tendency to aggregate during migration, the effect of multiple-year yellow-phase harvest on the same year class, and all harvests occurring before spawning (ASMFC 2000). As a result of the 2012 stock assessment, two addenda were added to the interstate fishery management plan to reduce American Eel mortality and increase conservation of stocks (ASMFC 2013). These addenda include new management for recreational and commercial glass eel, yellow-phase, and silver-phase fisheries.

Another potential contributor to the American Eel's population decline is its drastic habitat loss and extirpation from historic freshwater habitat in the last century (Verreault et al. 2004; USFWS 2007). Some habitat degradation is the result of dredging and filling channels as well as the loss of wetlands. Most loss of habitat and migration passageways is a result of dams. Some dams do not impede eel migration, but over 15,000 dams exist along Atlantic coastal streams, which have obstructed access to 84\% of the eel's historical habitat (Busch et al. 1998; Eyler 2014). Although few studies have examined the degree of impact that dams and their management practices have on migrating eels (Goodwin et al. 1999; ASMFC 2000), habitat fragmentation attributed to dams, hydroelectric facilities, and navigation weirs have reduced distribution ranges and increased extinction risks for migratory fishes including trout, pike, and minnow species (Agostinho et al. 2002; Ovidio and Philippart 2002). Over 90\% of the Atlantic coastal dams do not require re-licensing or fish passage analysis, because they are not considered 
hydroelectric facilities (ASMFC 2000; FERC 2004). Dams act as barriers that reduce the range and abundance of upstream migrating elvers as well as yellow-phase eels in the upper portions of watersheds (EPRI 2001; McCleave 2001; Goodwin and Angermeier 2003). Also, considering that eels in upper watershed regions typically differentiate as females, dams may affect sex ratios (Krueger and Oliveira 1999). Turbines at hydropower facilities can disrupt downstream migration and cause significant mortality rates of pre-spawning yellow- and silver-phase eels (Ritter et al. 1997; EPRI 1999; Haro et al. 2000; USFWS 2007). Turbine-induced mortality rates have ranged from 5\% to 100\% at different hydropower stations (ASMFC 2000; Jansen et al. 2007; Carr and Whoriskey 2008; Bruijs et al. 2009; Calles et al. 2010; Pedersen et al. 2012; Buysse et al. 2014). To combat the threats that dams pose to eels, researchers and fisheries managers have installed bypass structures and altered operation times at hydroelectric plants, turning off turbines at night when downstream migration is occurring. Eel ladders are also installed to aid in upstream migration (Whitfield and Kolenosky 1978; ASMFC 2000; Welsh and Liller 2013). Eels at different life stages require different ladder substrates in order to climb (EPRI 1999). While elvers are capable of ascending simple passageways comprised of gravel or mesh, yellow-phase eels often use vertical cylinders protruding from the bottom of the ladder for traction.

\section{Justification}

While the American Eel has gained attention in recent decades, little is understood about the species, especially young yellow-phase eels, and many unanswered questions remain. There is a growing need to study the species due to its economic and ecological importance as well as its population decline (Castonguay et al. 1994a; Haro et al. 2000; Casselman 2003; Verreault et al. 2004; COSEWIC 2006; Clark 2009). Historically, the species was an important food source 
for Native Americans and early settlers (Casselman 2003). The American Eel continues to be a valuable resource, playing an important role in today's international food market as well as supporting a commercial and domestic bait fishery (Castonguay et al. 1994a; Haro et al. 2000; Casselman 2003; ASMFC 2007). Ecologically, American Eels play an important role in aquatic ecosystems as a predator and prey species, being preyed upon by a variety of piscivorous fishes, mammals, and birds (Sinha and Jones 1967; Ogden 1970; Seymour 1974; Casselman 2003; Thompson et al. 2005; ASMFC 2007). They are also an important glochidia host in the Chesapeake Bay drainage for the freshwater mussel Elliptio complanata (Lellis et al. 2013). Given regional declines in abundance throughout its range, gaining a better understanding of the American Eel, especially knowledge of upstream migration, may be crucial for successful management and conservation (Oliveira and McCleave 2000; Wiley et al. 2004). This study examined the diel periodicity and chronology of upstream migration of yellow-phase American Eels and relationships between movement and total length in order to better understand upstream migration ecology and dam passage of yellow-phase American Eels at the Millville Dam eel ladder.

\section{Literature Cited}

Able, K. W., and M. P. Fahay. 1998. The first year in the life of estuarine fishes in the middle Atlantic bight. Rutgers University Press, Livingston Campus, New Brunswick, New Jersey. Pages 38-41.

Agostinho, A. A, L. C. Gomes, D. R. Fernandez, and H. I. Suzuki. 2002. Efficiency of fish ladders for neotropical ichthyofauna. River Research and Applications 18:299-306. Atlantic States Marine Fisheries Commission (ASMFC). 2000. Interstate fishery management plan for American Eel (Anguilla rostrata). ASMFC, Fishery Management Report 36 to NOAA, Washington, D.C. 
Atlantic States Marine Fisheries Commission (ASMFC). 2007. Review of the Atlantic SMFC fishery management plan for American Eel (Anguilla rostrata). Washington, D.C.

Atlantic States Marine Fisheries Commission (ASMFC). 2012. American Eel benchmark stock assessment. Raleigh, NC.

Atlantic States Marine Fisheries Commission (ASMFC). 2013. Review of the Atlantic SMFC fishery management plan for American Eel (Anguilla rostrata). Washington, D.C.

Barbin, G. P., S. J. Parker, and J. D. McCleave. 1998. Olfactory clues play a critical role in the estuarine migration of silver-phase American Eels. Environmental Biology of Fishes 53:283-291.

Barse, A. M., S. A. McGuire, M. A. Vinores, L. E. Eierman, and J. A. Weeder. 2001. The swimbladder nematode Anguillicola crassus in American Eels (Anguilla rostrata) from middle and upper regions of Chesapeake Bay. Journal of Parasitology 87:1366-1370.

Beak International Inc. 2001. The decline of the American Eel Anguilla rostrata in the Lake Ontario/St. Lawrence River ecosystem: A modeling approach to identification of data gaps and research priorities. Lake Ontario Committee: Great Lakes Fishery Commission Ann Arbor, Michigan.

Bergersen, R., and A. Klemetsen. 1988. Freshwater eel Anguilla anguilla (L.) from North Norway, with emphasis on occurrence, food, age, and downstream migration. Nordic Journal of Freshwater Research 64:54-66.

Bianchini, M., P. W. Sorensen, and H. E. Winn. 1982. Stima dell'abbondanza e shemi di movimento a breve raggio della anguilla Americana, Anguilla rostrata (LeSueur) (Pisces, Apodes), nel Narrow River, Rhode Island, USA. [Estimation of abundance and short range movements of the American Eel, Anguilla rostrata, in the Narrow River, Rhode Island, USA.] Naturalista Siciliano 6(Supplement 4):269-277.

Bruijs, M. C. M., R. H. Hadderingh, U. Schwevers, B. Adam, U. Dumont, and H. V. Winter. 2009. Managing human impact on downstream migrating European Eel in the River Meuse. Pages 381-390 In: J. M. Casselman and D. K. Cairns (editors), Eels at the edge: science, status, and conservation concerns. American Fisheries Society, Symposium 58, Bethesda, Maryland, 449 p. 
Busch, W., S. Larry, and C. Castiglione. 1998. Evaluating stream habitat for diadromous fish in Atlantic coast watersheds: a preliminary assessment. Habitat Hotline Atlantic, Atlantic States Marine Fisheries Commission 27:1-3.

Buysse, D., A. M. Mouton, M. Stevens, T. Van Den Neucker, J., and Coeck. 2014. Mortality of European Eel after downstream migration through two types of pumping stations. Fisheries Management and Ecology 21:13-21.

Cairns, D. K., and P. J. D. Hooley. 2003. Lunar cycles of American Eels in tidal waters of the Southern Gulf of the St. Lawrence, Canada. Pages 265-274 in D. A. Dixon, editor. Biology, management, and protection of catadromous eels. American Fisheries Society, Symposium 33, Bethesda, Maryland.

Cairns, D. K., V. Tremblay, F. Caron, J. M. Casselman, G. Verreault, B. M. Jessop, Y. de Lafontaine, R. G. Bradford, R. Verdon, P. Dumont, Y. Mailhot, J. Zhu, A. Mathers, K. Oliveira, K. Benhalima, J. Dietrich, J. A. Hallett, and M. Lagacé. 2008. American Eel abundance indicators in Canada. Canadian Data Report of Fisheries and Aquatic Sciences No. 1207.

Calles, O., I. C. Olsson, C. Comoglio, P. S. Kemp, L. Blunden, M. Schmitz, and L. A. Greenberg. 2010. Size-dependent mortality of migratory silver eels at a hydropower plant, and implications for escapement to the sea. Freshwater Biology 55:2167-2180.

Carr, J. W., and F. G. Whoriskey. 2008. Migration of silver American Eels past a hydroelectric dam and through a coastal zone. Fisheries Management and Ecology 15:393-400.

Casselman, J. M. 2003. Dynamics of resources of the American Eel, Anguilla rostrata: declining abundance in the 1990s. Pages 255-274 in Eel Biology. Springer-Verlag Tokyo, Japan.

Castonguay, M., P. V. Hodson, C. M. Couillard, M. J. Eckersley, J. D. Dutil and G. Verreault. 1994a. Why is recruitment of the American Eel, Anguilla rostrata, declining in the St. Lawrence River and Gulf? Canadian Journal of Fisheries and Aquatic Science 51:479_ 488.

Castonguay, M., P. V. Hodson, C. Moriarty, K. F. Drinkwater, and B. M. Jessop. 1994b. Is there a role of ocean environment in American and European Eel decline? Fisheries Oceanography 3:197-203. 
Castonguay, M., and J. D. McCleave. 1987. Vertical distributions, diel and otogenetic vertical migrations and net avoidance of leptacephali of Anguilla and other common species in the Sargasso Sea. Journal of Plankton Research 9:195-214.

Clark, J. H. 2009. The American Eel fishery in Delaware: recent landings trends and characteristics of the exploited eel population. Pages 229-239 in J. M. Casselman and D. K. Cairns, editors. Eels at the edge. Science, status, and Conservation Concerns American Fisheries Symposium 58, Bethesda, Maryland.

Committee on the Status of Endangered Wildlife in Canada (COSEWIC). 2006. COSEWIC assessment and status report on the American Eel Anguilla rostrata in Canada. Committee on the Status of Endangered Wildlife in Canada. Ottawa. $\mathrm{x}+71 \mathrm{pp}$.

Connaughton, M. A., and M. H. Taylor. 1995. Seasonal and daily cycles in sound production associated with spawning in the weakfish, Cynoscion regalis. Environmental Biology of Fishes 42:233-240.

Cottrill, A. R., S. R. McKinley, and G. Van Der Kraak. 2002. An examination of utilizing external measures to identify sexually maturing female American Eels, Anguilla rostrata, in the St. Lawrence River. Environmental Biology of Fishes 65:271-287.

de Lafontaine, Y., M. Lagacé, F. Gingras, D. Labonté, F. Marchand and E. Lacroix. 2009. Decline of the American Eel in the St. Lawrence River: effects of local hydroclimatic conditions on CPUE indices. Pages 207-229 in J. M. Casselman and D. K. Cairns, editors. Eels at the edge. Science, status, and Conservation Concerns American Fisheries Symposium 58, Bethesda, Maryland.

Dolan, J. A., and G. Power. 1977. Sex ratio of American Eels, Anguilla rostrata, from the Matamek River system, Quebec, with remarks on problems in sexual identification. Journal of the Fisheries Research Board of Canada 34:294-299.

Durif, C., P. Elie, C. Gosset, J. Rives, and F. Travade. 2003. Behavioral study of downstream migrating eels by radio telemetry at a small hydroelectric power plant. Pages 343-356 in D.A. Dixon (ed). Biology, Management, and Protection of Catadromous Eels. American Fisheries Society 33, Bethesda, Maryland.

Dutil, J. D., P. Dumont, D. K. Cairns, P. S. Galbraith, G. Verreault, M. Castonguay, and S. Proulx. 2009. Anguilla rostrata glass eel migration and recruitment in the estuary and Gulf of St Lawrence. Journal of Fish Biology 74:1970-1984. 
Dutil, J-D., A. Giroux, A. Kemp, G. Lavoie, and J-P. Dallaire. 1988. Tidal influence on movements and on daily cycle of activity of American Eels. Transactions of the American Fisheries Society 117:488-494.

Electrical Power Research Institute (EPRI). 1999. American Eel (Anguilla rostrata) scooping study: a literature and data review of life history, stock status, population dynamics, and hydroelectric impacts. EPRI, Palo Alto, California: TR-111873.

Electrical Power Research Institute (EPRI). 2001. Review and documentation of research and technologies on passage and protection of downstream migrating catadromous eels at hydroelectric facilities. EPRI, Palo Alto, California: TR-1000730.

Euston, E. T., D. D. Royer, and C. L. Simons. 1997. Relationship of emigration of silver American Eels (Anguilla rostrata) to environmental variables at a low head hydro station. Proceedings of the International Conference on Hydropower, August 5-8, 1997, Atlanta, Georgia.

Eyler, S. M. 2014. Timing and Survival of American Eels Migrating Past Hydroelectric Dams on the Shenandoah River. Doctoral dissertation. West Virginia University, Morgantown, West Virginia.

Facey, D.E., and M. J. Van Den Avyle. 1987. Species profiles: life histories and environmental requirements of coastal fishes and invertebrates (North Atlantic) - American Eel. U.S. Fish and Wildlife Service Biological Report 82(11.74). U.S. Army Corps of Engineers, TR EL-82-4.

Facey, D. E., and G. W. LaBar. 1981. Biology of American Eels in Lake Champlain, Vermont. Transactions of the American Fisheries Society 110:396-402.

Fahay, M. P. 1978. Biological and Fisheries Data on American Eel, Anguilla rostrata (LeSueur). Technical Series Report No. 17. National Marine Fisheries Service, NOAA, Highlands, New Jersey.

Federal Energy Regulatory Commission (FERC). 2004. Evaluation of mitigation effectiveness at hydropower projects: fish passage. Division of Hydropower Administration and Compliance. Office of Energy Projects. Federal Energy Regulatory Commission. September 2004.

Fish, J. F., and W. C. Cummings. 1972. A 50-dB increase in sustained ambient noise from fish (Cynoscion xanthulus). Journal of the Acoustical Society of America 52:1266-1270. 
Ford, T. E., and E. Mercer. 1986. Density, size distribution and home range of American Eels, Anguilla rostrata, in a Massachusetts salt marsh. Environmental Biology of Fishes 17:309-314.

Goodwin, K. R., and P. L. Angermeier. 2003. Demographic characteristics of American Eel in the Potomac River drainage, Virginia. Transactions of the American Fisheries Society 132:524-535.

Goodwin, K. R., P. L. Angermeier, and D. J. Orth. 1999. Final report: Assessing impacts of hydropower dams on upstream migration of American Eel. Report submitted to the Virginia Department of Game and Inland Fisheries Richmond, VA.

Gunning, G. E., and C. R. Shoop. 1962. Restricted movements of the American Eel, Anguilla rostrata (LeSueur), in freshwater streams, with comments on growth rate. Tulane Studies in Zoology 9:265-272.

Hammond, S. D., and S. A. Welsh. 2009. Seasonal movements of large yellow American Eels downstream of a hydroelectric dam, Shenandoah River, West Virginia. Pages 309-323 in J. M. Casselman and D. K. Cairns, editors. Eels at the edge: science, status, and conservation concerns. American Fisheries Society Symposium 58, Bethesda, Maryland.

Haro, A. 2003. Downstream migration of silver-phase anguillid eels. Pages 215-222 in Eel Biology. Springer-Verlag Tokyo, Japan.

Haro, A. J., W. Richkus, K. Whalen, A. Hoar, W. D. Busch, S. Lary, T. Brush, and D. Dixon. 2000. Population decline of the American Eel: implications for research and management. Fisheries 25:7-16.

Helfman, G. S. 1986. Diel distribution and activity of American Eels (Anguilla rostrata) in a cave-spring. Canadian Journal of Fisheries and Aquatic Sciences 43:1595-1605.

Helfman, G. S., D. E. Facey, L. S. Hales, and E. L. Bozeman. 1987. Reproductive ecology of the American Eel. American Fisheries Society Symposium 1:42-56.

Helfman, G. S., D. L. Stoneburner, E. L. Bozeman, P. A. Christian, and R. Whalen. 1983. Ultrasonic telemetry of American Eel movements in a tidal creek. Transactions of the American Fisheries Society 112:105-110.

Helfman, G. S, E. L. Bozeman, and E. B. Brothers. 1984. Size, age, and sex of American Eels in a Georgia River. Transactions of the American Fisheries Society 113:132-141. 
Holt, J. G., S. A. Holt, and C. R. Arnold. 1985. Diel periodicity of spawning in sciaenids. Marine Ecology Progressive Series 27:1-7.

Jansen, H. A., H. V. Winter, M. C. M. Bruijs, and H. J. G. Polman. 2007. Just go with the flow? Route selection and mortality during downstream migration of silver eels in relation to river discharge. ICES Journal of Marine Science 64:1437-1443.

Jessop, B. M. 1987. Migrating American Eels in Nova Scotia. Transactions of the American Fisheries Society 116:161-170.

Jessop, B. M. 2003. Annual variability in the effects of water temperature, discharge, and tidal stage on the migration of American Eel elvers from estuary to river. Pages 3-16 in D. A. Dixon, editor. Biology, management, and protection of catadromous eels. American Fisheries Society, Symposium 33, Bethesda, Maryland.

Jessop, B. M. 2010. Geographic effects on American Eel (Anguilla rostrata) life history characteristics and strategies. Canadian Journal of Fisheries and Aquatic Sciences 67:326-346.

Kennedy, C. R. 2007. The pathogenic helminth parasites of eels. Journal of Fish Diseases 30:319-334.

Kirk, R. S. 2003. The impact of Anguillicola crassus on European Eels. Fisheries Management and Ecology 10:385-394.

Kleckner, R. C., J. D. McCleave, and G. S. Whipplehauser. 1983. Spawning of American Eel, Anguilla rostrata, relative to thermal fronts in the Sargasso Sea. Environmental Biology of Fishes 9:289-293.

Kleckner, R., and J. McCleave. 1985. Spatial and temporal distribution of American Eel larvae in relation to North Atlantic current systems. Dana 4:67-92.

Knights, B. 2003. A review of the possible impacts of long-term oceanic and climate changes and fishing mortality on recruitment of anguillid eels of the Northern Hemisphere. The Science of the Total Environment 310:237-244.

Krueger, W. H., and K. Oliveira. 1997. Sex, size, and gonad morphology of silver American Eels Anguilla rostrata. Copeia 1997(2):415-420.

Krueger, W. H., and K. Oliveira. 1999. Evidence for environmental sex determination in the American Eel, Anguilla rostrata. Environmental Biology of Fishes 55:38-389. 
Laffaille, P., A. Acou, J. Guillouet, and A. Legault. 2005. Temporal changes in European Eel, Anguilla anguilla, stocks in a small catchment after installation of fish passes. Fisheries Management and Ecology 12:123-129.

Lamothe, P. J., M. Gallagher, D. P. Chivers, and J. M. Moring. 2000. Homing and movement of yellow-phase American Eels in freshwater ponds. Environmental Biology of Fishes 58:393-399.

Lellis, W. A., B. S. J. White, J. C. Cole, C. S. Johnson, J. L. Devers, E. V. S. Gray, and H. S. Galbraith. 2013. Newly documented host fishes for the eastern elliptio mussel Elliptio complanata. Journal of Fish and Wildlife Management 4:75-85.

Lobel, P. S. 1978. Diel, lunar, and seasonal periodicity in the reproductive behavior of the pomacanthid fish, Centropyge potteri, and some other reef fishes in Hawaii. Pacific Science 32:193-207.

Locascio, J. V., and D. A. Mann. 2008. Diel periodicity of fish sound production in Charlotte Harbor, Florida. Transactions of the American Fisheries Society 137:606-615.

Lowe, R. H. 1952. The influence of light and other factors on the seaward migration of the silver eel, Anguilla anguilla. Journal of Animal Ecology 21:275-309.

MacGregor, R., A. Mathers, P. Thompson, J. M. Casselman, J. M., Dettmers, S. LaPan, T. C. Pratt, and B. Allen. 2008. Declines of American Eel in North America: complexities associated with bi-national management. Pages 357-381 in International governance of fisheries ecosystems: learning from the past, finding solutions for the future. American Fisheries Society 62, Bethesda, Maryland.

Marcogliese, L. A., and J. M. Casselman. 2009. Long term trends in size and abundance of juvenile American Eels ascending the upper St. Lawrence River. Pages 191-205 in J. M. Casselman and D. K. Cairns, editors. Eels at the Edge: Science, Status, and Conservation Concerns. American Fisheries Society 58, Bethesda, Maryland.

Martin, M. H. 1995. The effects of temperature, river flow, and tidal cycles on the onset of glass eel and elver migration into fresh water in the American Eel. Journal of Fish Biology 46:891-902.

McCleave, J. D. 2001. Simulation of the impact of dams and fishing weirs on reproductive potential of silver-phase American Eels in the Kennebec River basin, Maine. North American Journal of Fisheries Management 21:592-605. 
McCleave, J. D., and R. C. Kleckner. 1987. Distribution of leptocephali of the catadromous Anguilla species in the western Sargasso Sea in relation to water circulation and migration. Bulletin of Marine Science 41:789-806.

McCleave, J. D., R. C. Kleckner, and M. Castonguay. 1987. Reproductive sympatry of American and European Eel and implications for migration and taxonomy. American Fisheries Society Symposium 1:268-297.

McCleave, J. D., and G. S. Wippelhauser. 1987. Behavioral aspects of selective tidal stream transport in juvenile American Eels. American Fisheries Society Symposium 1:138-150.

McGrath, K. J., D. Desrochers, C. Fleury, and J. W. Dembeck, IV. 2003. Studies of upstream migrant American Eels at the Moses-Saunders Power Dam on the St. Lawrence River near Massena, New York. Pages 153-166 in D. A. Dixon, editor. Biology, management, and protection of catadromous eels. American Fisheries Society 33, Bethesda, Maryland.

Meffe, G. K., and A. L. Sheldon. 1988. The influence of habitat structure on fish assemblage composition in southeastern blackwater streams. The American Midland Naturalist 120:225-240.

Miles, S.G. 1968. Rheotaxis of elvers of the American Eel (Anguilla rostrata) in the laboratory to water from different streams in Nova Scotia. Journal of Fisheries Resources Board of Canada 25:1591-1602.

Mok, H. K., and R. G. Gilmore. 1983. Analysis of sound production in estuarine fish aggregations of Pogonias cromis, Bairdiella chrysoura, and Cynoscion nebulosus (Sciaenidae). Bulletin of the Institute of Zoology, Academia Sinica (Taipei) 22:157-186.

Neraas, L. P., and P. Spruell. 2001. Fragmentation of riverine systems: the genetic effects of dams on Bull Trout (Salvelinus confluentus) in the Clark Fork River System. Molecular Ecology 10:1153-1164.

Ogden, J. C. 1970. Relative abundance, food habits, and age of the American Eel, Anguilla rostrata (LeSueur), in certain New Jersey streams. Transactions of the American Fisheries Society 1:54-59.

Oliveira, K. 1997. Movements and growth rates of yellow-phase American Eels in the Annaquatucket River, Rhode Island. Transactions of the American Fisheries Society 126:638-646. 
Oliveira, K. 1999. Life history characteristics and strategies of the American Eel, Anguilla rostrata. Canadian Journal of Fisheries and Aquatic Sciences 56:795-802.

Oliveira, K., and J. D. McCleave. 2000. Variation in population and life history traits of the American Eel, Anguilla rostrata, in four rivers in Maine. Environmental Biology of Fishes 59:141-151.

Oliveira, K., and J. D. McCleave. 2002. Sexually different growth histories of the American Eel in four rivers of Maine. Transactions of the American Fisheries Society 131:203-211.

Ovidio, M., and J. Philippart. 2002. The impact of small physical obstacles on upstream movements of six species of fish. Hydrobiologia 483:55-69.

Palstra, A. P., D. F. M. Heppener, V. J. T. van Ginneken, C. Székely, and G. E. E. J. M. van den Thillart. 2007. Swimming performance of silver eels is severely impaired by the swimbladder parasite Anguillicola crassus. Journal of Experimental Marine Biology and Ecology 352:244-256.

Pankhurst, N. W., and P. W. Sorensen. 1984. Degeneration of the alimentary tract in sexually maturing European Anguilla anguilla (L.) and American Eels Anguilla rostrata (LeSueur). Canadian Journal of Zoology 62:1143-1149.

Parker, S. J. 1995. Homing ability and home range of yellow-phase American Eels in a tidally dominated estuary. Journal of the Marine Biological Association of the United Kingdom 75:127-140.

Parker, S. J., and J. D. McCleave. 1997. Selective tidal stream transport by American Eels during homing movements and estuarine migration. Journal of Marine Biology Association U.K. 77:8713-889.

Pedersen, M. I., N. Jepsen, K. Aarestrup, A. Koed, S. Pedersen, and F. Økland. 2012. Loss of European silver eel passing a hydropower station. Journal of Applied Ichthyology 28:189-193.

Powles, P. M., and S. M. Warlen. 2001. Recruitment season, size, and age of young American Eels (Anguilla rostrata) entering an estuary near Beaufort, North Carolina. Fisheries Bulletin 100:299-306.

Richkus, W., and K. Whalen. 2000. Evidence for a decline in abundance of American Eel, Anguilla rostrata (LeSueur), in North America since the early 1980s. Dana 12:83-97. 
Ritter, J. A., M. Stanfield, and R. H. Peterson. 1997. Final Discussion. Pages 170-172 in R.H. Peterson (ed) The American Eel in eastern Canada: stock status and management strategies. Proceedings of eel management workshop, January 13-14, 1997, Quebec City, PQ. Canadian Technical Report of Fisheries and Aquatic Sciences 2196.

Robinet, T. T., and E. E. Feunteun. 2002. Sublethal effects of exposure to chemical compounds: a cause for the decline in Atlantic eels? Ecotoxicology 11:265-277.

Saucier, M. H., and D. M. Baltz. 1993. Spawning site selection by spotted seatrout, Cynoscion nebulosus, and black drum, Pogonias cromis, in Louisiana. Environmental Biology of Fishes 36:257-272.

Schmidt, J. 1923. The breeding places of the eel. Philosophical Transactions of the Royal Society of London Series B 211:179-208.

Schmidt, R. E., C. M. O’Reilly, and D. Miller. 2009. Observations of American Eels using an upland passage facility and effects of passage on the population structure. North American Journal of Fisheries Management 29:715-720.

Seymour, N. R. 1974. Great black-backed gulls feeding on live eel. Canadian Field Naturalist $8: 352-353$.

Sinha, V. R. P., and J. W. Jones. 1967. On the food of the freshwater eel and their feeding relationship with salmonids. Journal of Zoology (London) 153:119-137.

Smith, M. W., and J. W. Saunders. 1955. The American Eel in certain fresh waters of the Maritime Provinces of Canada. Journal of the Fisheries Research Board of Canada $12: 238-269$.

Smogor, R. A., P. L. Angermeier, and C. K. Gaylord. 1995. Distribution and abundance of American Eels in Virginia streams: tests of null models across spatial scales. Transactions of the American Fisheries Society 124:789-803.

Sorensen, P. W., and M. L. Bianchini. 1986. Environmental correlates of the freshwater migration of elvers of the American Eel in a Rhode Island Brook. Transactions of the American Fisheries Society 115:258-268.

Sorensen, P.W., M. Bianchini, and H.E. Winn. 1986. Diel feeding activity of American Eels, Anguilla rostrata (LeSueur), in a Rhode Island estuary. Fishery Bulletin 84:201-202. 
Strickland, P. A. 2002. American Eel distribution and growth in selected tributaries of the James River. Master's thesis. Virginia Polytechnic Institute and State University, Blacksburg, Virginia.

Takemura, A., T. Takita, and K. Mizue. 1978. Studies on the underwater sound VII: underwater calls of the Japanese marine drum fishes (Sciaenidae). Bulletin of the Japanese Society of Scientific Fisheries 44:121-125.

Tesch, F. W. 1977. The eel. Biology and management of anguillid eels. Chapman and Hall, London.

Thompson, C.M., P.E. Nye, G.A. Schmidt, and D.K. Garcelon. 2005. Ecology of bald eagles in a freshwater tidal system. Journal of Wildlife Management 69:609-617.

U.S. Fish and Wildlife Service (USFWS). 2007. Endangered and threatened wildlife and plants; 12-month finding on a petition to list the American Eel as threatened or endangered, Proposed Rules (50 CFR Part 17), Federal Register 72:22(2 February 2007):4967-4997.

U.S. Fish and Wildlife Service (USFWS). 2011. Endangered and threatened wildlife and plants; 90-day finding on a petition to list the American Eel as threatened, Proposed Rules (50 CFR Part 17), Federal Register 76:189(29 September 2011):60431-60444.

Van Den Avyle, M. 1984. Species profiles: life histories and environmental requirements of coastal fishes and invertebrates (South Atlantic) American Eel. U.S. Fish and Wildlife Service. FWS/OBS-82/11.24. U.S. Army Corps of Engineers, TR EL-82-4.

Verdon, R., and D. Desrochers. 2003. Upstream migratory movements of American Eel Anguilla rostrata between the Beauharnois and Moses-Saunders power dams on the St. Lawrence River. Pages 139-152 in D. A. Dixon, editor. Biology, management, and protection of catadromous eels. American Fisheries Society, Symposium 33, Bethesda, Maryland.

Verdon, R., D. Desrochers, and P. Dumont. 2003. Recruitment of American Eels in the Richelieu River and Lake Champlain: provision of upstream passage as a regional-scale solution to a large-scale problem. Pages 125-138 in D.A. Dixon, editor. Biology, Management, and protection of catadromous eels. American Fisheries Society, Symposium 33, Bethesda, Maryland.

Verreault G., P. Dumont, and Y. Mailhot. 2004. Habitat losses and anthropogenic barriers as a cause of population decline for American Eel (Anguilla rostrata) in the St. Lawrence 
watershed, Canada. ICES CM 2004/S:04. 2004 ICES Annual Science Conference, Vigo, Spain.

Vøllestad, L., A. B. Johnson, N. A. Hridsten, T. F. Naesje, O. Haraldstad, and J. Ruud-Hansen. 1986. Environmental factors regulating the seaward migration of European silver eels (Anguilla anguilla). Canadian Journal of Fisheries and Aquatic Sciences 43:1909-1916.

Walsh, P. J., G. D. Foster, and T. W. Moon. 1983. The effects of temperature on metabolism of the American Eel Anguilla rostrata compensation in the summer and torpor in the winter. Physiological Zoology 56:532-540.

Welsh, S. A., and J. L. Aldinger. 2014. A semi-automated method for monitoring dam passage of upstream migrant yellow-phase American Eels. North American Journal of Fisheries Management 34:702-709.

Welsh, S. A., J. L. Aldinger, M. A. Braham, and J. L. Zimmerman. 2015. Synergistic and singular effects of river discharge and lunar illumination on dam passage of upstream migrant yellow-phase American Eels. ICES Journal of Marine Science doi: 10.1093/icesjms/fsv052.

Welsh, S. A., and H. L. Liller. 2013. Environmental correlates of upstream migration of yellowphase American Eels in the Potomac River drainage. Transactions of the American Fisheries Society 142:483-491.

Whitfield, R. E., and D. P. Kolenosky. 1978. Prototype eel ladder in the St. Lawrence River. The Progressive Fish-Culturist 40:152-154.

Wiley, D., R. P. Morgan, and R. H. Hilderbrand. 2004. Relations between physical habitat and American Eel abundance in five river basins in Maryland. Transactions of the American Fisheries Society 133:515-526.

Winn, H. E., W. A. Richkus, and L. K. Winn. 1975. Sexual dimorphism and natural movements of the American Eel (Anguilla rostrata) in Rhode Island streams and estuaries. Helgoländer Wissenschaftliche Meeresuntersuchungen 27:156-166.

Zacchei, A. M., and P. Tavolaro. 1988. Lateral line system during the life cycle of Anguilla anguilla (L.). Bollettino di Zoologia 55(3):145-153.

Zimmerman, J. L., and S. A. Welsh. 2012. Prevalence of Anguillicoloides crassus and growth variation in migrant yellow-phase American Eels of the upper Potomac River drainage. Diseases of aquatic organisms 101:131-137. 


\title{
Chapter 2: Diel periodicity and chronology of upstream migration in yellow-phase American Eels (Anguilla rostrata)
}

\author{
ABSTRACT \\ This study examined the diel periodicity and chronology of upstream migration of \\ yellow-phase American Eels (Anguilla rostrata) and relationships between movement and total \\ length. Passage count data were collected during 2011-2014 at the Millville Dam eel ladder on \\ the lower Shenandoah River, West Virginia. Six multi-day passage events with a high number of \\ passage counts were selected for analysis and categorized by diel periods of movement \\ (vespertine, nocturnal, matutinal, and diurnal) and season (spring, summer, late summer/early \\ fall, fall). To examine periodicity of movements, I graphically-depicted these data as time-series \\ histograms and used time-series spectral analysis (Fast Fourier Transformation, FFT) to identify \\ cyclical patterns and diel periodicity of upstream migration. I also created histograms to examine \\ movement patterns within diel periods for each passage event and described multiple peaks of \\ passage counts for vespertine, nocturnal, and matutinal movements by fitting normal mixture \\ models (2-9 mixtures). A mixed-model methodology was used to examine relationships among \\ total length (TL), diel period, and season. Periodicity of movements closely followed a 24-h \\ cycle of activity for each multi-day passage event with most movement occurring nocturnally. \\ To my knowledge, this is the first study to quantify the pattern of diel periodicity of upstream \\ migration using spectral analysis. Based on mixture model analysis, distribution patterns and \\ timing of upstream migration were relatively complex and variable across seasons, although \\ there were some similarities across the six passage events. Multimodal models were supported \\ by the data, where most modes represented nocturnal movements, but modes at or near the \\ transition between periods of twilight and night were also common. For the mixed-model \\ analysis of TL, the additive-effects model of diel period + season was selected as the best \\ approximating model. Based on values of mean TL, a decreasing trend occurred across diel \\ movement periods (vespertine $=311.5 \mathrm{~mm} \pm 1.7 \mathrm{SE}$, nocturnal $=305.8 \mathrm{~mm} \pm 0.59 \mathrm{SE}$, matutinal \\ $=298.3 \mathrm{~mm} \pm 1.9 \mathrm{SE}$, and diurnal $=282.8 \mathrm{~mm} \pm 5.5 \mathrm{SE}, \mathrm{n}=58)$. Also, mean TL was highest \\ during fall $(330.3 \mathrm{~mm} \pm 1.9 \mathrm{SE})$ relative to similar mean values of TL for spring $(304.1 \mathrm{~mm} \pm$ \\ 1.0 SE), summer (301.2 $\mathrm{mm} \pm 1.1 \mathrm{SE})$ and late summer/early fall (303.4 $\mathrm{mm} \pm 0.87 \mathrm{SE})$. This \\ study increased our understanding of upstream migration ecology of yellow-phase American \\ Eels and dam passage at the Millville Dam eel ladder.
}

\section{INTRODUCTION}

The American Eel (Anguilla rostrata) is a catadromous species with a complex life history, including larval, glass, elver, yellow, and silver phases (Tesch 1977; Facey and Van Den Avyle 1987; Oliveira 1999). The species spends a large portion of its life in the yellow phase, the dominant growth phase, during which many individuals migrate long distances upstream, often facing migration barriers, such as dams (Tesch 1977; Facey and Van Den Avyle 1987; ASMFC 
2000). The upstream migration ecology of the American Eel is not well understood, particularly little is known about the periodicity and timing chronology of upstream movements. In the last few decades, eel ladders have been installed on some Atlantic Coast rivers, providing opportunities to study and monitor upstream movements of American Eels (McGrath et al. 2003; Verdon et al. 2003; Schmidt et al. 2009; Welsh and Liller 2013; Welsh et al. 2015). Further studies on the upstream migration ecology of the yellow-phase American Eel, however, are relevant to management and conservation efforts, given migration barriers on upstream movements and recent concerns of population decline (Haro et al. 2000; Richkus \& Whalen 2000; Casselman 2003).

Bianchini et al. (1982), as cited in Oliveira (1997) hypothesized a punctuated pattern of upstream migration, where short-term home ranges of American Eels alternate with long-range movements. Interestingly, punctuated patterns of upstream migration may occur at several temporal and spatial scales. Annually, punctuated upstream movements are due, in part, to seasonal changes in water temperature. Walsh et al. (1983) and Renaud and Moon (1980) reported torpor and reduced feeding at $10^{\circ} \mathrm{C}$ in juvenile American Eels. Yellow-phase American Eels cease upstream movements during fall when water temperatures reach $10^{\circ} \mathrm{C}(\mathrm{McGrath}$ et al. 2003; Hammond and Welsh 2009) and resume upstream movements the following spring during water temperatures of $\sim 15-20^{\circ} \mathrm{C}$ (K. McGrath, pers. comm.; Welsh et al. 2015). In addition to water temperature, other environmental variables have been associated with punctuated upstream movements, including periods of dark lunar phases and periods of increased river discharge (Welsh and Liller 2013; Welsh et al. 2015).

Diel periodicity of upstream migration is expected for American Eels, because upstream movements are punctuated by nocturnal or crepuscular behavior, as American Eels primarily 
move at night or twilight, although some movements have been observed during the day (Helfman 1986; Sorensen et al. 1986; Dutil et al.1988; McGrath et al. 2003; Verdon et al. 2003; Welsh and Aldinger 2014). Few studies, however, have examined the timing of upstream migration within diel periods (day, twilight, and night). McGrath et al. (2003) and Verdon et al. (2003) documented the timing (30-min increments) of upstream migrants at eel ladders on the St. Lawrence and Richelieu Rivers, respectively. From these studies, McGrath et al. (2003) and Verdon et al. (2003) emphasized the predominance of nocturnal movements, but did not separate movements for twilight and night periods.

This study examined diel periodicity, passage timing, and lengths of upstream migrant yellow-phase American Eels at the Millville Dam eel ladder on the lower Shenandoah River, West Virginia from 2011-2014. Study objectives were to (1) examine diel periodicity of upstream migrants using time-series spectral analysis, (2) describe the distribution of passage counts during diel periods (day, twilight, and night) among seasons (spring, summer, and fall), and (3) examine size of upstream migrants relative to diel and seasonal periods.

\section{METHODS}

Study site

The 296-m-wide Millville hydroelectric dam (owned and operated by PE Hydro Generation, LLC) stands five meters tall and is located on the lower Shenandoah River, approximately nine rkm upstream of the confluence of the Shenandoah and Potomac rivers, 100 rkm upstream of the Potomac River at the head of tide, and $285 \mathrm{rkm}$ upstream from the mouth of the Potomac River estuary (Welsh and Liller 2013; Welsh et al. 2015). An 11-m eel ladder with a $50^{\circ}$ slope (Milieu Inc, Quebec, Canada) is installed annually on the western end of the dam. The eel ladder, a stainless steel-covered sluice that contains a peg board climbing substrate, is 
typically in operation from spring or summer through fall to aid upstream migration (Welsh and Liller 2013; Welsh et al. 2015).

\section{Data collection}

Data on passage counts from digital photographs, including date and time of passage, were downloaded from an infrared-triggered digital camera located near the apex of the eel ladder (Welsh 2014). The digital photographs were also used to obtain photogrammetric measurements of American Eel lengths as described by Welsh and Aldinger (2014). River flow, lunar phase, and astronomical data were also collected for the passage events. Daily estimates of river discharge $\left(\mathrm{m}^{3} / \mathrm{s}\right)$ of the Shenandoah River were obtained from the U.S. Geological Survey gage located approximately $400 \mathrm{~m}$ downstream of the Millville Dam (http://waterdata.usgs.gov). I calculated the illuminated fraction of the moon for each passage event in package oce (version 0.9-14, Kelley 2014) in program R (version 3.1.3 R Development Core Team 2015), where the fraction ranged from 0.00 (new moon) to 1.00 (full moon). I collected daily astronomical data for Millville Dam using the package maptools (version 0.8-36, Bivand et al. 2015) in program R (version 3.1.3 R Development Core Team 2015) and classified activity periods for a 24-h cycle based on the rising and setting of the sun. Because eels exhibit crepuscular and nocturnal behavior (Sorensen et al. 1986; Meffe and Sheldon 1988; Hammond and Welsh 2009), I separated upstream movements by periods of twilight, night, and day:

- Vespertine $=$ movements during dusk period between sunset and evening astronomical twilight (i.e., when the sun is $0-18^{\circ}$ below the horizon);

- Matutinal $=$ movements during dawn period between sunrise and morning astronomical twilight (i.e., when the sun is $0-18^{\circ}$ below the horizon);

- $\quad$ Diurnal $=$ movements during the daytime period between sunrise and sunset; or 
- Nocturnal $=$ movements during the nighttime period after astronomical twilight ends in the evening and before astronomical twilight begins the next morning.

\section{Data analysis}

I analyzed six multi-day passage events, which ranged in length from 7 to 18 days. The six passage events were selected based on time periods that had high passage counts within a short time frame, which reduced variation associated with temporal (i.e., seasonal) changes in lengths of twilight, nighttime, and daylight periods. These six passage events were categorized as four seasonal periods: spring (17-28 May 2012, n=1,848), summer (12-21 July 2013, n=1,617, and 22 July-3 August 2014, n=285), late summer/early fall (13 September-1 October 2011, n=666, and 18-27 September 2012, $\mathrm{n}=1,868)$, and fall (14-21 October 2014, $\mathrm{n}=519)$.

To examine periodicity of movements, I aggregated counts of individuals passing through the ladder into 10-min bins for each multi-day passage event starting at 12:00 noon on the first day and ending at 12:00 noon on the last day. I graphically-depicted these data as time-series histograms, including a secondary y-axis for river discharge $\left(\mathrm{m}^{3} / \mathrm{s}\right)$ to emphasize the relationship between upstream movements and river discharge as previously reported by Welsh et al. (2015). I examined the histogram data with time-series spectral analysis (Fast Fourier Transformation, FFT) to identify cyclical patterns and diel periodicity of American Eel upstream migration (JMP, version 12.0.1 SAS Institute Inc. 2015). An FFT classifies data by component frequencies using an algorithm to convert time to frequency while finding sinusoidal patterns (Chatfield 1996). Frequencies of dominant patterns are represented as peaks in periodograms and can be graphically depicted as time (x-axis) by spectral density (y-axis) (Meyer et al. 2007; Baluev 2013). I applied FFTs to count data for each of the six passage events and added a reference line to the time axis to indicate the dominant frequency. 
To examine patterns of vespertine, nocturnal, and matutinal movements for each passage event, I created histograms of the number of individuals passing through the ladder pooled into a 14-h period (18:00-08:00 hours) using 10-min bins. As a descriptive approach, I fit a normal model to the histogram data for each passage event representing a hypothesis of a unimodal peak. Additionally, I fit eight normal mixture models (2-9 mixtures) representing hypotheses of multimodal distributions (JMP, version 12.0.1 SAS Institute Inc. 2015). Using these nine candidate models, I used Bayesian information criterion (BIC, Schwarz 1978) to select the best approximating model (Steele and Raftery 2010). This analysis approach allowed for the description of multiple modes or peaks of passage counts for vespertine, nocturnal, and matutinal movements.

A mixed-model methodology was used to examine relationships among total length (TL), diel period, and season (SAS 9.4, PROC MIXED). Given that the TL of individuals passing within a 24-h diel period may not be independent, this approach adjusted covariance structure of the models through a random block effect on TL within each 24-h period (12:00 to 12:00 hours). I fit the following four models to TL data: (1) an intercept model, (2) a diel period model, (3) a season model, and (4) an additive-effects model of diel period + season. I used BIC as a model selection criterion. To aid interpretation of model selection, I plotted descriptive statistics of mean $\pm \mathrm{SE}$ of TL for categories of movements during diel periods (vespertine, nocturnal, matutinal, diurnal) and seasons (spring, summer, late summer/early fall, fall). I did not have data for every season of every year. Therefore, I modeled seasons separately and could not test for a year effect. Also, given that passage events were selected from time periods of high counts associated with increased river discharge and often with new moon periods (Welsh et al. 2015), I did not expect to find relationships between TL, river discharge, and lunar illumination. 
Therefore, I did not fit models with covariates of river discharge and lunar illumination.

However, as a separate analysis, I did depict these relationships by plotting the log TL and log river discharge and $\log \mathrm{TL}$ and lunar illumination.

\section{RESULTS}

A total passage count of 9,042 individuals was recorded at the Millville eel ladder during 2011-2014, including annual counts of 1255 (6 May-9 November 2011), 4263 (28 June-7 November 2012), 2470 (1 July-12 October 2013), and 1054 (22 July-5 November 2014). I reduced variation associated with temporal changes in lengths of twilight, night, and day periods by analyzing six short-term passage events representing $75.2 \%(n=6,803)$ of the total number of individuals that used the eel ladder during 2011-2014. Total lengths were photogrammetrically measured for 5,989 of the 6,803 individuals, with a mean TL of $305.2 \mathrm{~mm} \pm 0.55 \mathrm{SE}$, range $=$ $185-609 \mathrm{~mm}$.

Time series data of passage events separated into 10-min intervals depicted diel periodicity of upstream movements, where most individuals moved during periods of twilight and night, and few individuals moved during the day (Figures 2.1, 2.2). Peaks in movement for the multi-day passage events were associated with an increase in river discharge (Figure 2.1). For diel periods, the counts of vespertine, nocturnal, matutinal, and diurnal movements were 506 (7.4\%), 5,625 (82.7\%), $588(8.6 \%)$, and $84(1.2 \%)$, respectively. For each passage event, timeseries spectral analysis using FFT recovered dominant frequencies representing 24-h cycles (Figure 2.1).

Based on mixture model analysis, multimodal models were supported by the data. Multimodal patterns of movement differed across the six passage events, but there were some similarities in timing of modal peaks (Table 2.1, Appendix 2.1). Most movement peaks occurred 
during the nighttime period, although three of the six periods had peaks for vespertine or matutinal movements. All passage events had peaks during the middle of the nighttime period (0:00-02:00, Figure 2.2), which is likely the darkest part of the night. Also, peaks in movement occurred at or near the transitions of evening twilight/night, and night/morning twilight in 4 of 6 and 5 of 6 passage events, respectively (Figure 2.2). For the spring passage event, a four-mixture model was supported, with a modal movement peak during each twilight period, and two peaks during the night period (Figure 2.2A). For the first summer passage event, a six-mixture model was supported by the data, with single modal peaks for vespertine and matutinal movements and four peaks of nocturnal movements (Figure 2.2B). For the second summer passage event, however, data supported only three movement peaks, including two for nocturnal movements and one at the transition of night and early morning twilight (Figure 2.2C). The first and second passage events of late summer/early fall contained eight and six peaks, respectively, where all peaks were during the nighttime period, except for a single peak of matutinal movement (Figures 2.2D, 2.2E). The fall passage event included four peaks of nocturnal movements and no peaks during twilight periods (Figure 2.2F).

For the mixed-model analysis of TL, the additive-effects model of diel period + season was selected as the best approximating model (BIC $=-7686.0$ ), where BIC values for the intercept, diel period, and season models were $-7676.1,-7650.5$, and -7679.1 , respectively. The additive-effects model was visually supported and interpreted with use of descriptive statistics, where mean TL depicted a decreasing trend across diel periods (vespertine $=311.5 \mathrm{~mm} \pm 1.7 \mathrm{SE}$, $\mathrm{n}=235 ;$ nocturnal $=305.8 \mathrm{~mm} \pm 0.59 \mathrm{SE}, \mathrm{n}=5182 ;$ matutinal $=298.3 \mathrm{~mm} \pm 1.9 \mathrm{SE}, \mathrm{n}=514$; and day $=282.8 \mathrm{~mm} \pm 5.5 \mathrm{SE}, \mathrm{n}=58$; Figure 2.3). Also, mean $\mathrm{TL}$ was highest during fall (330.3 $\mathrm{mm} \pm 1.9 \mathrm{SE}, \mathrm{n}=472)$ relative to similar mean values of $\mathrm{TL}$ for spring $(304.1 \mathrm{~mm} \pm 1.0 \mathrm{SE}, \mathrm{n}=$ 
1700), summer (301.2 $\mathrm{mm} \pm 1.1 \mathrm{SE}, \mathrm{n}=1548)$ and late summer/early fall $(303.4 \mathrm{~mm} \pm 0.87 \mathrm{SE}$, $\mathrm{n}=2269$; Figures 2.4, 2.5). The higher mean TL of individuals undergoing vespertine movements did not influence the higher mean TL during fall passage (14-21 October 2014), as vespertine movements were not observed during the fall passage event. Separate correlation analyses of $\log \mathrm{TL}$ and $\log$ river discharge and $\log \mathrm{TL}$ and lunar illumination supported weak relationships ( $\mathrm{r}=0.1$, Figure 2.6; $\mathrm{r}=0.05$, Figure 2.7; respectively).

\section{DISCUSSION}

While studies have suggested that American Eels exhibit nocturnal or crepuscular behavior (Sorensen et al. 1986; Meffe and Sheldon 1988; Hammond and Welsh 2009), to my knowledge, this is the first study to quantify diel periodicity of upstream migration of yellowphase American Eels. It is well established that American Eels are primarily nocturnal (Helfman et al. 1983; Helfman 1986; Sorensen et al. 1986; Dutil et al.1988, 1989; Meffe and Sheldon 1988; Parker 1995), thus diel periodicity of movements would be expected to closely follow a 24-h cycle of activity. Based on six multi-day passage events during this study, time-series spectral analysis found a dominant frequency at $24 \mathrm{~h}$. While studies have examined the periodicity of movement (Bohun and Winn 1966; Helfman et al. 1983; Sorensen and Bianchini 1986), I am unaware of other studies using spectral and FFT analysis for American Eel upstream migration; however, FFT has been used in several recent studies to identify periodicity in movements of various fish species (Graham et al. 2006; Shepard et al. 2006; Meyer et al. 2007; Afonso et al. 2009; Brunnschweiler and Sims 2011).

Few studies have addressed diel chronology and timing of upstream movements of yellow-phase American Eels during periods of twilight and night. The majority of movements in this study were nocturnal, and all six events had peaks of movement occurring during the middle 
of the nighttime period. Dutil et al. (1989) observed movements of glass and elver American Eels in the Gulf of St. Lawrence occurring primarily between 21:00 and 23:00. In a study of upstream migrant yellow-phase eels at an eel pass on the Moses-Saunders Power Dam, St. Lawrence River, McGrath et al. (2003) reported nocturnal movements where most individuals (94\%) used the ladder between 19:30 and 05:30 hours. During a three-year study (1997-1999) of the Chambly Dam eel ladder, Richelou River, Verdon et al. (2003) reported the diel timing of eel use as mostly nocturnal, from 21:00 hours to dawn, with a peak near 1:00 hours. My results support that upstream migrants primarily undergo nocturnal movements, which is consistent, in part, with McGrath et al. (2003) and Verdon et al. (2003). However, McGrath et al. (2003) and Verdon et al. (2003) used passage data of eel counts for 30-min periods and did not separate periods of day, twilight, and night, whereas my data represented 10-min time periods, and separated day, twilight, and night based on time periods of astronomical twilight. Also, it is interesting to note that all passage events had peaks during the middle of the nighttime period (0:00-02:00, Figure 2.1), likely the darkest part of the night. It is possible that some American Eels select darker conditions when migrating to avoid the risk of predation.

Although the distribution patterns and timing of upstream migration in this study were complex and variable across seasons, there were some similarities. The majority of peaks in movement were nocturnal, and five of the passage events had movement peaks occurring near the interfaces of twilight (vespertine and matutinal movements) and night, which supports previous studies finding that eels exhibit nocturnal and crepuscular behavior. There are several simple biologically reasonable hypotheses for diel chronology and timing of upstream movements. One hypothesis, which would represent a unimodal distribution, is where upstream migrants initiate vespertine movements at dusk, depict a modal peak of nocturnal movements 
during the night, and continue with matutinal movements at a decreasing rate until dawn. However, my data did not support a unimodal distribution. Additionally, bimodal distributions, which were not supported by the data, could result from peaks of vespertine and nocturnal movements, or peaks of nocturnal and matutinal movements. Another hypothesis, which would represent three distributions, would involve modal peaks of vespertine, nocturnal, and matutinal movements, but this distribution pattern was also not supported by the data. Based on my observational data, I was not able to explain why distribution patterns of diel chronology and timing of upstream migration were relatively complex (three to eight modal peaks). I was also not able to explain why the most complex distribution patterns occurred during the two passage events of late summer/early fall. Peaks in movement, however, occurred at or near the interfaces of evening twilight and night, and night and morning twilight in 4 of 6 and 5 of 6 passage events, respectively. This finding is consistent with experimental studies by Bohun and Winn (1966), who reported that locomotor activity in 203-305 mm American Eels was highest at times of light change, corresponding to dusk and dawn periods, and by Edel (1976), who found bursts in activity during times of light change. Helfman (1986) also observed that changes in the movements of American Eels in a Florida cave-spring occurred around dusk and dawn.

The diel chronology of upstream migrants using the eel ladder may be linked to the longitudinal distribution of individuals downstream of the dam, the initial distance downstream of the dam prior to starting vespertine or nocturnal movements, and the speed of upstream migration. Assuming a constant rate of upstream migration, individuals closest to the dam may find the eel ladder sooner than those farther from the dam. Another consideration is the variation in search time among individuals in finding the ladder entrance. Presumably, there is a time delay from when an upstream migrant reaches the dam and when it finds the eel ladder entrance. 
This may explain why peaks in vespertine movements were only observed during two of six passage events.

The mean TL of individuals passing the dam followed a time trend where the longest individuals used the ladder during evening twilight (vespertine movements) and the shortest individuals used the ladder during the day (diurnal movements). Our finding of larger individuals moving during the vespertine period is not influenced by the fall period (14-21 October 2014), because we did not have TL data for any vespertine movement of that period (Figure 2.5D). To my knowledge, no other studies have documented a difference in TL of upstream migrants among diel periods of day, twilight, and night. Although the eel ladder is expected to pass upstream migrants, it is also possible that American Eels with established home ranges just downstream of the dam may also use the ladder. American Eels with established home ranges will likely have higher mean TL than upstream migrants, and if proximately located downstream of the dam would have a relatively short distance of travel to reach the dam during vespertine movements. Ford and Mercer (1986) found in Great Sippewissett Marsh, Falmouth, Massachusetts, that the average size of individuals decreased as their home range distance upstream increased; however, they found no relationship between size of individuals and distance of diel movement. It is also unclear why smaller individuals moved during the daytime period.

The mean TL of individuals passing during the fall exceeded that of individuals migrating upstream during the spring, summer, and late summer/early fall periods. Similarly, Welsh and Liller (2013) reported mean TL of upstream migrants during 2004-2005 at Millville Dam as $29.3 \mathrm{~cm} \pm 0.13 \mathrm{SE}$ (during a spring/summer period), $30.2 \mathrm{~cm} \pm 0.23 \mathrm{SE}$ (late spring/summer period), and $33.6 \mathrm{~cm} \pm 0.12 \mathrm{SE}$ (late summer/early fall period). Dutil et al. (1989) 
also found a decrease in the proportion of smaller sized eels in the Gulf of St. Lawrence as the migration season progressed. Although I found no studies examining the effect of water temperature on different size eels, I speculate that the influence of colder water temperatures on the activity of larger individuals may be less than that of smaller individuals, particularly during fall when water temperatures are between 10 and $15^{\circ} \mathrm{C}$, but I was not able to test this hypothesis with observational data. Hammond and Welsh (2009) found that larger yellow-phase eels (518$810 \mathrm{~mm}$ TL) were active during fall time periods with mean water temperatures as low as $9.3^{\circ} \mathrm{C}$.

This study examined the timing chronology of upstream migration of yellow-phase American Eels among and within 24-h (diel) periods. In summary, it quantified the pattern of diel periodicity of upstream migration. Based on the time-series spectral analysis of six multi-day passage events, periodicity of movements closely followed a 24-h cycle of activity with the majority of movements were nocturnal with a few peaks occurring near the interfaces of twilight (vespertine and matutinal periods) and night, which supports previous studies finding that eels exhibit nocturnal and crepuscular behavior (Sorensen et al. 1986; Meffe and Sheldon 1988; McGrath et al. 2003; Verdon et al. 2003; Hammond and Welsh 2009). The distribution patterns and timing of upstream migration were complex and variable. The TL of individuals passing the dam followed a chronological trend with time, where the longest individuals passed through the ladder during the vespertine period and the shortest individuals used the ladder during the day (diurnal movements). The mean TL of individuals passing was greater during the fall period than that of individuals using the ladder during the spring, summer, and late summer/early fall periods, which supports the results found by Dutil et al. (1989), Hammond and Welsh (2009), and Welsh and Liller (2013). 
While this study provides insight into the patterns of upstream migration of yellow-phase American Eels in the Shenandoah River, I realize that correlative effects associated with observational data limit strong inference. Also, inference is restricted to the lower Shenandoah River, as I do not know if these results are representative of other watersheds within the geographic range of American Eels. Future studies of similar design including multiple watersheds could offer a better understanding of upstream migration throughout the American Eel's geographic distribution. This could be especially useful in areas where the number of individuals passing during the upstream migration season is much greater and there is a larger TL range. This study did not consider the presence of artificial light and did not measure the amount of ambient light at the Millville Dam, which would be an interesting variable to include in future, similar studies. Based on the 24-h cycle and the range of time for movement peaks, our study suggests that the monitoring counts of individuals migrating upstream should occur on a nightly basis and throughout the entire night (i.e., from sunset to sunrise) to ensure inclusion of most upstream migrants.

\section{LITERATURE CITED}

Afonso, P., J. Fontes, K. N. Holland, and R. S. Santos. 2009. Multi-scale patterns of habitat use in a highly mobile reef fish, the White Trevally, Pseudocaranx dentex, and their implications for marine reserve design. Marine Ecology Progress Series 381:273-286.

Atlantic States Marine Fisheries Commission (ASMFC). 2000. Interstate fishery management plan for American Eel (Anguilla rostrata). ASMFC, Fishery Management Report 36 to NOAA, Washington, D.C.

Baluev, R. V. 2013. Detecting multiple periodicities in observational data with the multifrequency periodogram, I. Analytic assessment of the statistical significance. Monthly Notices of the Royal Astronomical Society 1-13. 
Bianchini, M., P. W. Sorensen, and H. E. Winn. 1982. Stima dell'abbondanza e shemi di movimento a breve raggio della anguilla Americana, Anguilla rostrata (LeSueur) (Pisces, Apodes), nel Narrow River, Rhode Island, USA. [Estimation of abundance and short range movements of the American Eel, Anguilla rostrata, in the Narrow River, Rhode Island, USA.] Naturalista Siciliano 6(Supplement 4):269-277.

Bivand, R., N. Lewin-Koh, E. Pebesma, E. Archer, Baddeley, H. Bibiko, S. Brey, J. Callahan, G. Carrillo, S. Dray, D. Forrest, M. Friendly, P. Giraudoux, D. Golicher, V. Gómez Rubio, P. Hausmann, K. O. Hufthammer, T. Jagger, S. Luque, D. MacQueen, A. Niccolai, E. Pebesma, O. Perpiñán Lamigueiro, T. Short, G. Snow, B. Stabler, M. Stokely, R. Turner. 2015. Maptools: tools for reading and handling spatial objects. R package version 0.8-36. Available:http://r-forge.r-project.org/projects/maptools/.

Bohun, S., and H. E. Winn. 1966. Locomotor activity of the American Eel (Anguilla rostrata). Chesapeake Science 7:1137-147.

Brunnschweiler, J. M., and D. W. Sims. 2011. Diel oscillations in whale shark vertical movements associated with meso- and bathypelagic diving. American Fisheries Society Symposium 76:1-13.

Casselman, J. M. 2003. Dynamics of resources of the American Eel, Anguilla rostrata: declining abundance in the 1990s. Pages 255-274 in Eel Biology. Springer-Verlag Tokyo, Japan.

Chatfield, C. 1996. The analysis of time series: an introduction, 6th edition. Chapman \& Hall, London.

Dutil, J-D., A. Giroux, A. Kemp, G. Lavoie, and J-P. Dallaire. 1988. Tidal influence on movements and on daily cycle of activity of American Eels. Transactions of the American Fisheries Society 117:488-494.

Dutil, J. D., M. Michaud, and A. Giroux. 1989. Seasonal and diel patterns of stream invasion by American Eels (Anguilla rostrata) in the northern Gulf of St. Lawrence. Canadian Journal of Zoology 67:182-188.

Edel, R. K. 1976. Activity rhythms of maturing American Eels (Anguilla rostrata). Marine Biology 3:283-289.

Facey, D. E., and M. J. Van Den Avyle. 1987. Species profiles: life histories and environmental requirements of coastal fishes and invertebrates (North Atlantic) - American Eel. U.S. 
Fish and Wildlife Service Biological Report 82(11.74). U.S. Army Corps of Engineers, TR EL-82-4.

Ford, T. E., and E. Mercer. 1986. Density, size distribution and home range of American Eels, Anguilla rostrata, in a Massachusetts salt marsh. Environmental Biology of Fishes 17:309-314.

Graham, R. T., C. M. Roberts, and J. C. Smart. 2006. Diving behaviour of whale sharks in relation to a predictable food pulse. Journal of the Royal Society Interface 3:109-116.

Hammond, S. D., and S. A. Welsh. 2009. Seasonal movements of large yellow American Eels downstream of a hydroelectric dam, Shenandoah River, West Virginia. Pages 309-323 in J. M. Casselman and D. K. Cairns, editors. Eels at the edge: science, status, and conservation concerns. American Fisheries Society Symposium 58, Bethesda, Maryland.

Haro, A. J., W. Richkus, K. Whalen, A. Hoar, W. D. Busch, S. Lary, T. Brush, and D. Dixon. 2000. Population decline of the American Eel: implications for research and management. Fisheries 25:7-16.

Helfman, G. S. 1986. Diel distribution and activity of American Eels (Anguilla rostrata) in a cave-spring. Canadian Journal of Fisheries and Aquatic Sciences 43:1595-1605.

Helfman, G. S., D. L. Stoneburner, E. L. Bozeman, P. A. Christian, and R. Whalen. 1983. Ultrasonic telemetry of American Eel movements in a tidal creek. Transactions of the American Fisheries Society 112:105-110.

Kelley, D. 2014. Oce: analysis of oceanographic data. R package version 0.9-14. Available: http://www.CRAN.R-project.org/package=oce.

McGrath, K. J., D. Desrochers, C. Fleury, and J. W. Dembeck, IV. 2003. Studies of upstream migrant American Eels at the Moses-Saunders Power Dam on the St. Lawrence River near Massena, New York. Pages 153-166 in D. A. Dixon, editor. Biology, management, and protection of catadromous eels. American Fisheries Society 33, Bethesda, Maryland.

Meffe, G. K., and A. L. Sheldon. 1988. The influence of habitat structure on fish assemblage composition in southeastern blackwater streams. The American Midland Naturalist 120:225-240.

Meyer, C. G., K. N. Holland, and Y. P. Papastamatiou. 2007. Seasonal and diel movements of giant trevally Caranx ignobilis at remote Hawaiian atolls: implications for the design of marine protected areas. Marine Ecology Progress Series 333:13-25. 
Oliveira, K. 1997. Movements and growth rates of yellow-phase American Eels in the Annaquatucket River, Rhode Island. Transactions of the American Fisheries Society 126:638-646.

Oliveira, K. 1999. Life history characteristics and strategies of the American Eel, Anguilla rostrata. Canadian Journal of Fisheries and Aquatic Sciences 56:795-802.

Parker, S. J. 1995. Homing ability and home range of yellow-phase American Eels in a tidally dominated estuary. Journal of the Marine Biological Association of the United Kingdom 75:127-140.

R Development Core Team. 2015. R: A language and environment for statistical computing. R Foundation for Statistical Computing, Vienna, Austria. Available: http://www.Rproject.org.

Renaud, J. M., and Moon, T. W. 1980. Characterization of gluconeogenesis in hepatocytes isolated from the American Eel, Anguilla rostrata LeSueur. Journal of comparative physiology 135:115-125.

Richkus, W., and K. Whalen. 2000. Evidence for a decline in abundance of American Eel, Anguilla rostrata (LeSueur), in North America since the early 1980s. Dana 12:83-97.

SAS Institute Inc. 2015. JMP version 12.0.1. Available: http://www.jmp,com.

Schmidt, R. E., C. M. O'Reilly, and D. Miller. 2009. Observations of American Eels using an upland passage facility and effects of passage on the population structure. North American Journal of Fisheries Management 29:715-720.

Schwarz, G. 1978. Estimating the dimension of a model. The Annals of Statistics 6:461-464.

Shepard, E. L., M. Z. Ahmed, E. J. Southall, M. J. Witt, J. D. Metcalfe, and D. W. Sims. 2006. Diel and tidal rhythms in diving behaviour of pelagic sharks identified by signal processing of archival tagging data. Marine Ecology Progress Series 328:205-213.

Sorensen, P. W., and M. L. Bianchini. 1986. Environmental correlates of the freshwater migration of elvers of the American Eel in a Rhode Island Brook. Transactions of the American Fisheries Society 115:258-268.

Sorensen, P. W., M. Bianchini, and H. E. Winn. 1986. Diel feeding activity of American Eels, Anguilla rostrata (LeSueur), in a Rhode Island estuary. Fishery Bulletin 84:201-202. 
Steele, R. J., and A. Raftery. 2010. Performance of Bayesian model selection criteria for Gaussian mixture models. Frontiers of statistical decision making and Bayesian analysis 113-130.

Tesch, F. W. 1977. The eel. Biology and management of anguillid eels. Chapman and Hall, London.

Verdon, R., D. Desrochers, and P. Dumont. 2003. Recruitment of American Eels in the Richelieu River and Lake Champlain: provision of upstream passage as a regional-scale solution to a large-scale problem. Pages 125-138 in D.A. Dixon, editor. Biology, Management, and protection of catadromous eels. American Fisheries Society, Symposium 33, Bethesda, Maryland.

Walsh, P. J., G. D. Foster, and T. W. Moon. 1983. The effects of temperature on metabolism of the American Eel Anguilla rostrata compensation in the summer and torpor in the winter. Physiological Zoology 56:532-540.

Welsh, S. A. 2014. Photographic animal counter for monitoring movement of aquatic animals. U.S. patent 8,651,057 B1. February 18, 2014.

Welsh, S. A., and J. L. Aldinger. 2014. A semi-automated method for monitoring dam passage of upstream migrant yellow-phase American Eels. North American Journal of Fisheries Management 34:702-709.

Welsh, S. A., J. L. Aldinger, M. A. Braham, and J. L. Zimmerman. 2015. Synergistic and singular effects of river discharge and lunar illumination on dam passage of upstream migrant yellow-phase American Eels. ICES Journal of Marine Science doi: 10.1093/icesjms/fsv052.

Welsh, S. A., and H. L. Liller. 2013. Environmental correlates of upstream migration of yellowphase American Eels in the Potomac River drainage. Transactions of the American Fisheries Society 142(2):483-491. 

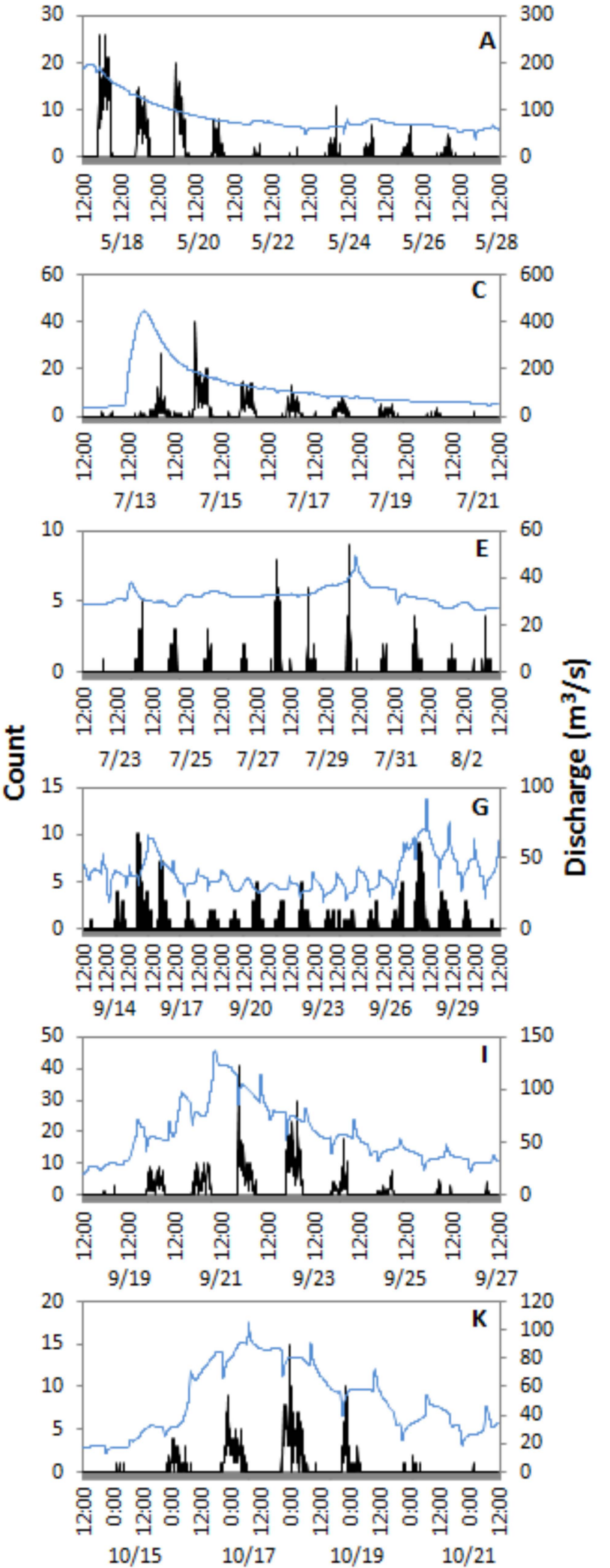

Time/date
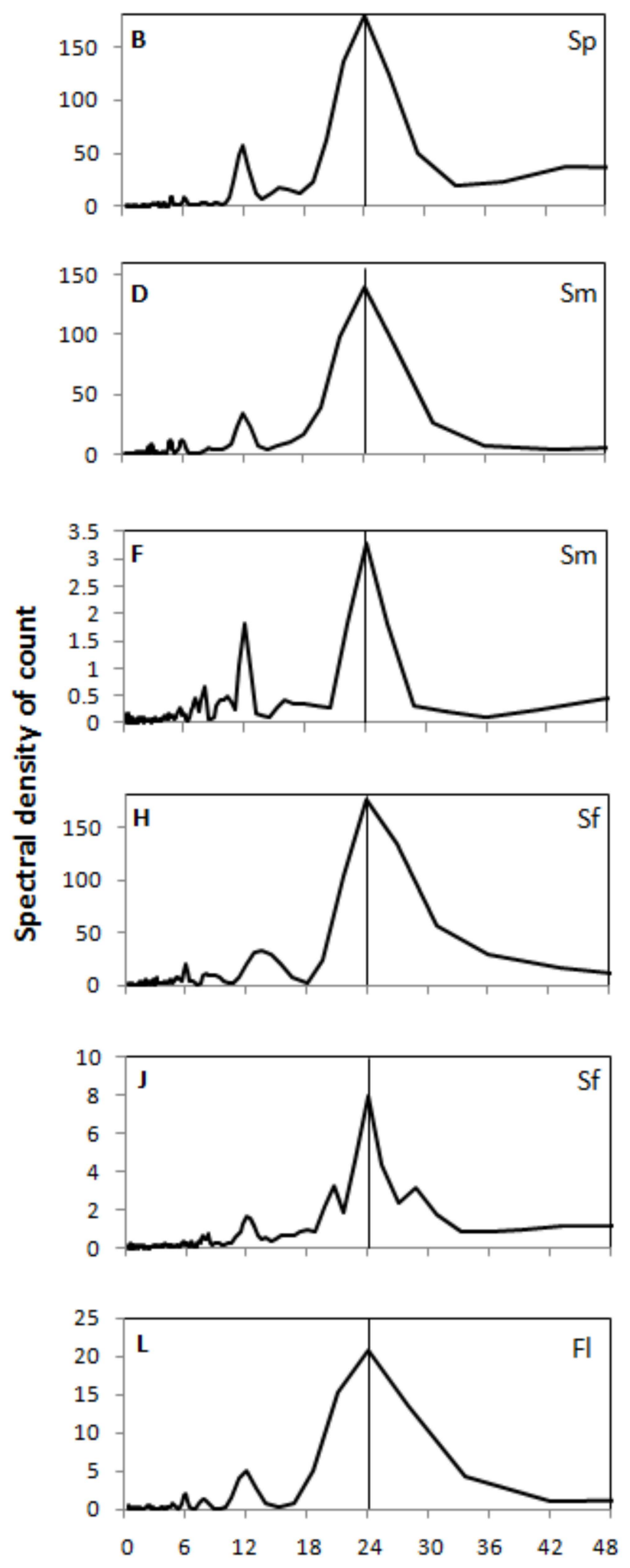

Period (h)

Figure 2.1. Frequency of counts of American Eels passing through the eel ladder and river discharge $\left(\mathrm{m}^{3} / \mathrm{s}\right)$ at the Millville Dam using 10-min bins (starting at 12:00 on the first day of the period) for six periods: 17-28 May 2012 (A, B), 12-21 July 2013 (C, D), 22 July-3 August 2014 (E, F), 13 September-1 October 2011 (G, H), 18-27 September 2012 (I, J), and 14-21 October 2014 (K, L). Seasons are labeled as spring (SP), summer (SM), late summer/early fall (SF), and fall (FL). A reference line indicates the dominant frequency 

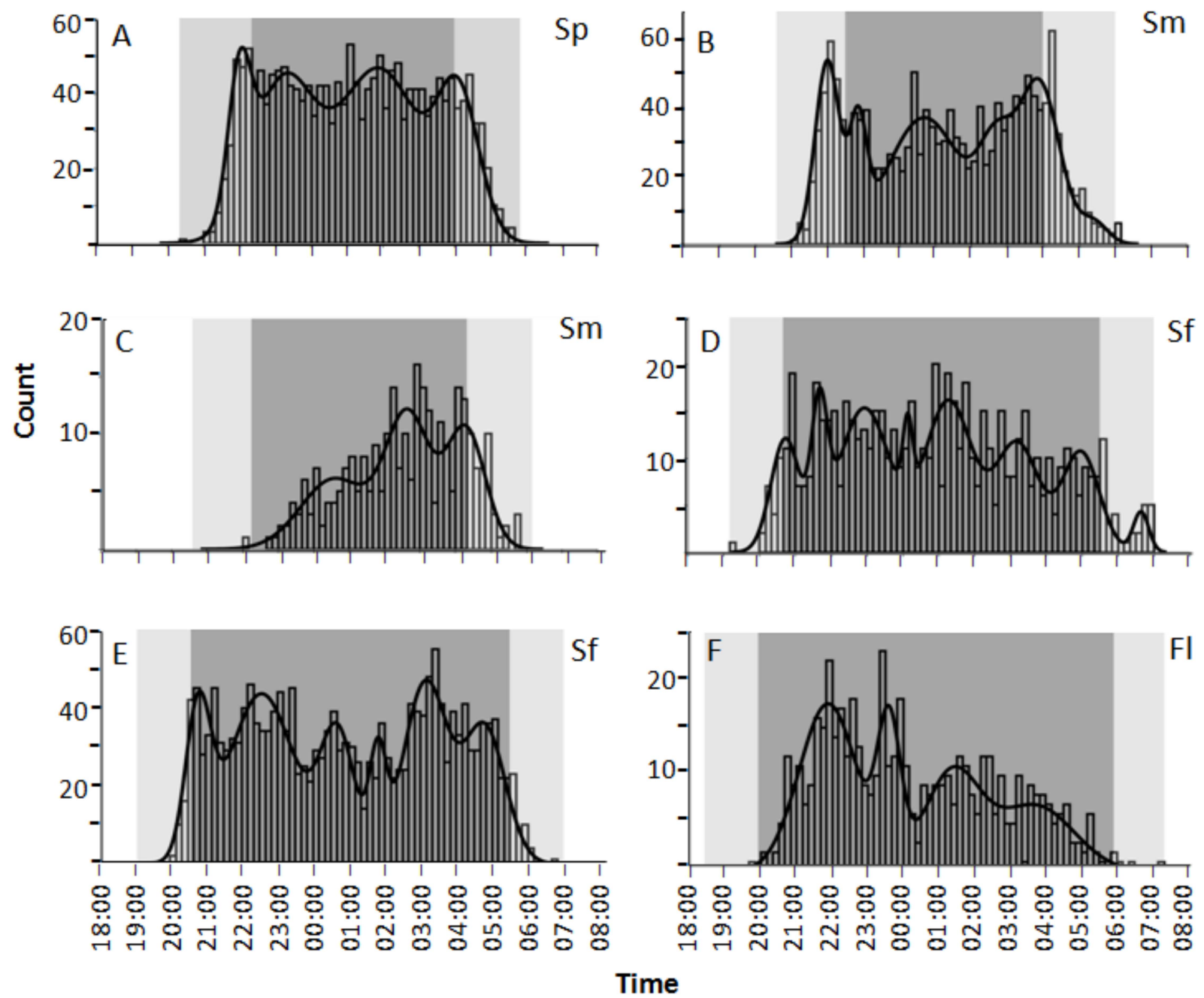

Figure 2.2. Frequency of counts of American Eels passing through the Millville Dam eel ladder on the Shenandoah River pooled into a $14 \mathrm{~h}$ period (starting at 18:00) using 10-min bins for six periods: 17-28 May 2012 (A), 12-21 July 2013 (B), 22 July-3 August 2014 (C), 13 September-1 October 2011 (D), 18-27 September 2012 (E), and 1421 October $2014(\mathrm{~F})$. The lighter shaded areas represent twilight periods (vespertine and matutinal movements) and the dark shaded area represents night (nocturnal movements). Seasons are labeled as spring (SP), summer (SM), late summer/early fall (SF), and fall (FL). 


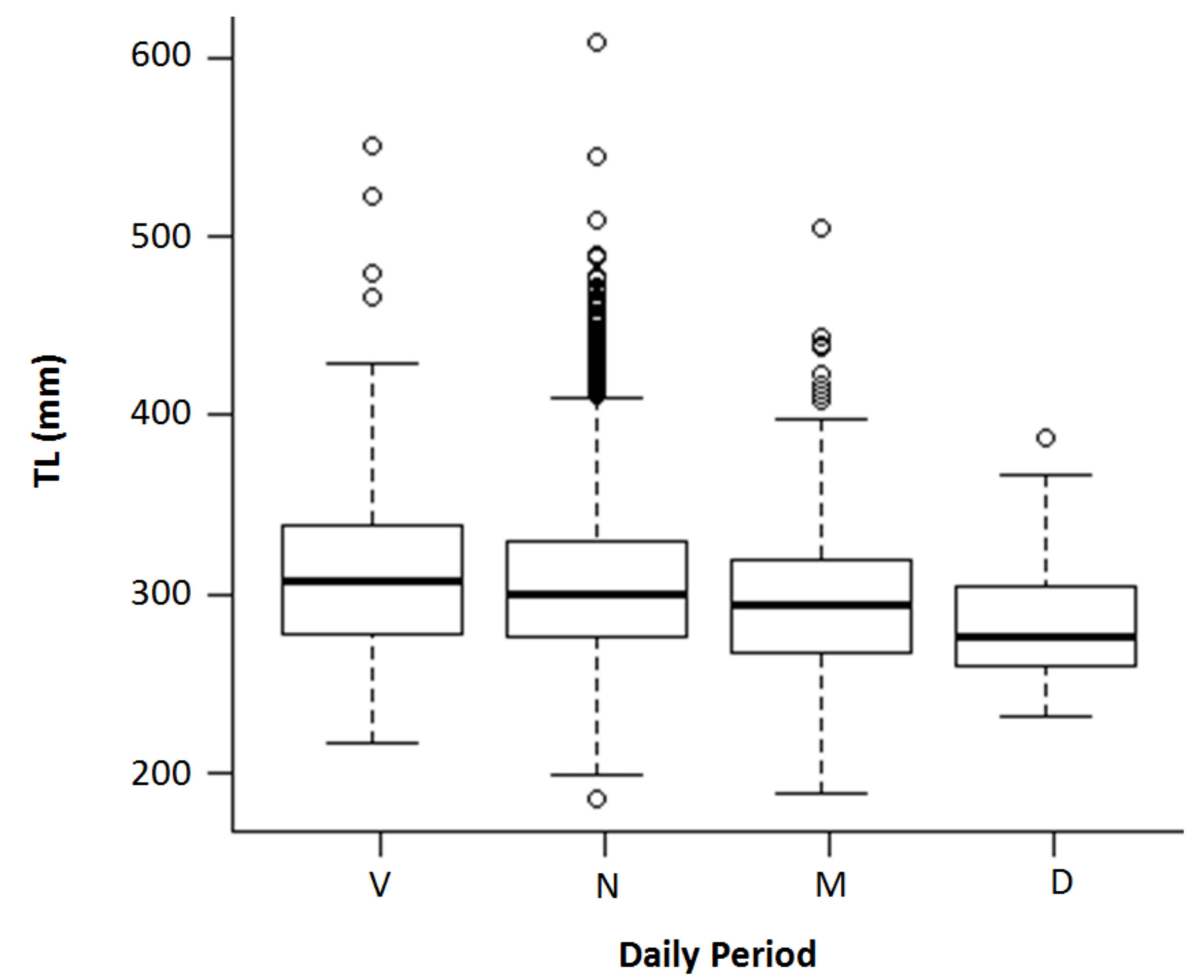

Figure 2.3. Descriptive statistics of TL (mm) of American Eels using the Millville Dam eel ladder during four diel periods of movement (vespertine $=\mathrm{V}$, nocturnal $=\mathrm{N}$, matutinal $=\mathrm{M}$, and diurnal $=\mathrm{D}$ ). Means for each period are represented with a bolded line, boxes indicate $25 \%$ and $75 \%$ quantiles, and tails indicate $95 \%$ confidence intervals. Points indicate outliers.

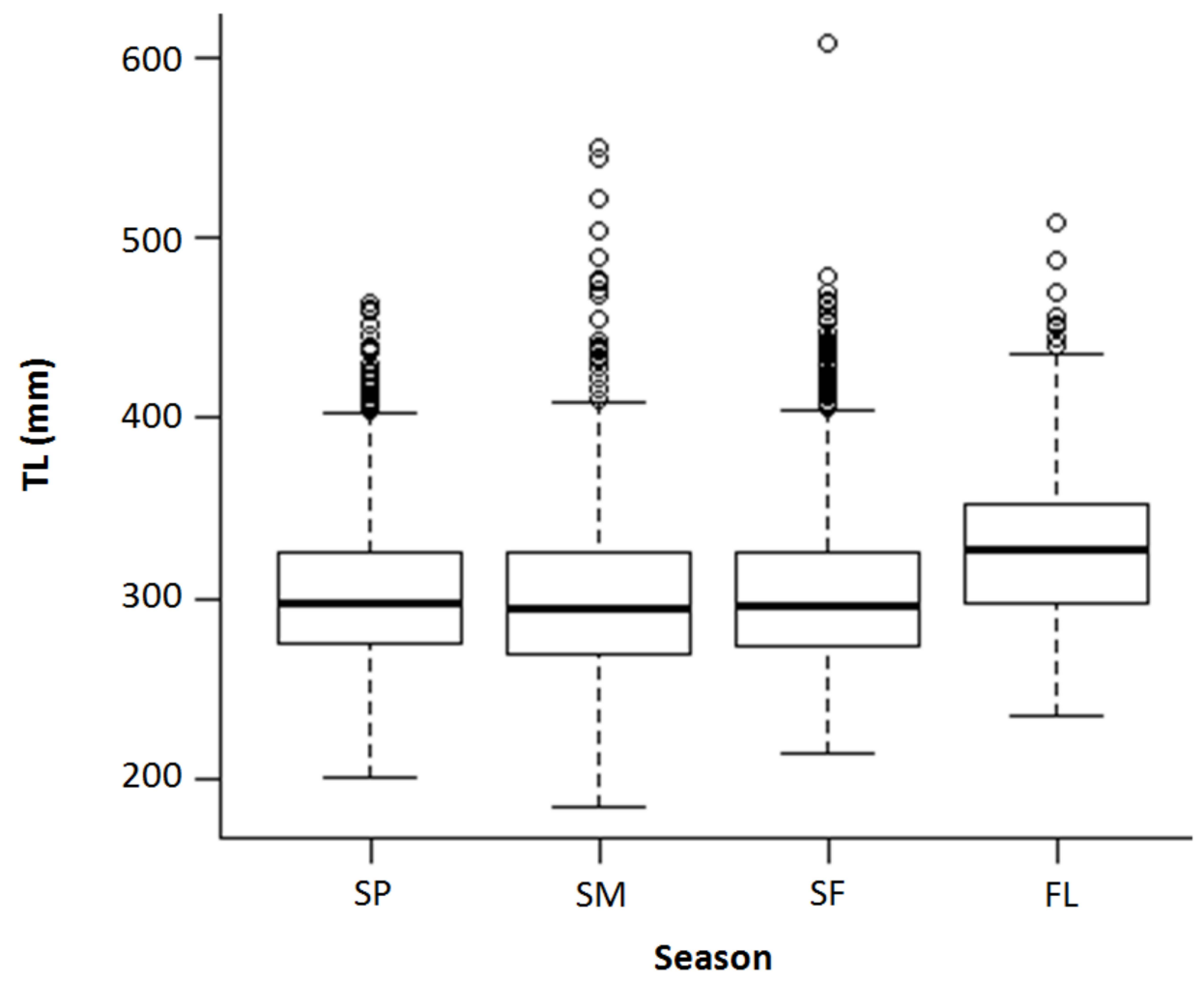

Figure 2.4. Descriptive statistics of TL ( $\mathrm{mm}$ ) of American Eels using the Millville Dam eel ladder during four seasonal periods (spring=SP, summer=SM, late summer/early fall=SF, and fall=FL). Means for each season are represented with a bolded line, boxes indicate $25 \%$ and $75 \%$ quantiles, and tails indicate $95 \%$ confidence intervals. Points indicate outliers. 


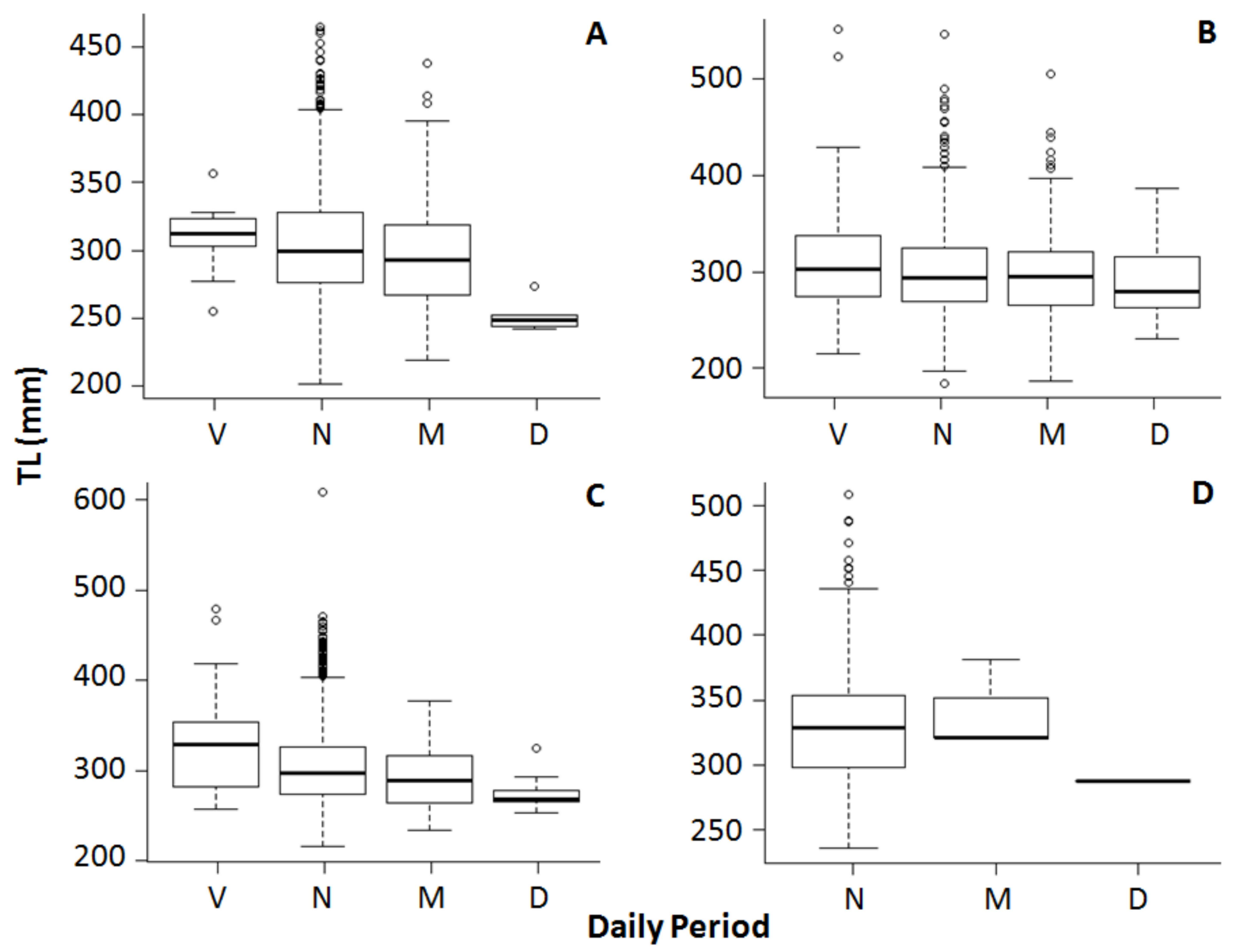

Figure 2.5. Descriptive statistics of TL ( $\mathrm{mm}$ ) of American Eels using the Millville Dam eel ladder during four diel periods of movement (vespertine=V, nocturnal=N, matutinal=M, and diurnal=D) for spring (A), summer (B), late summer/early fall (C), and fall (D). Means for each season are represented with a bolded line, boxes indicate $25 \%$ and $75 \%$ quantiles, and tails indicate $95 \%$ confidence intervals. Points indicate outliers. 


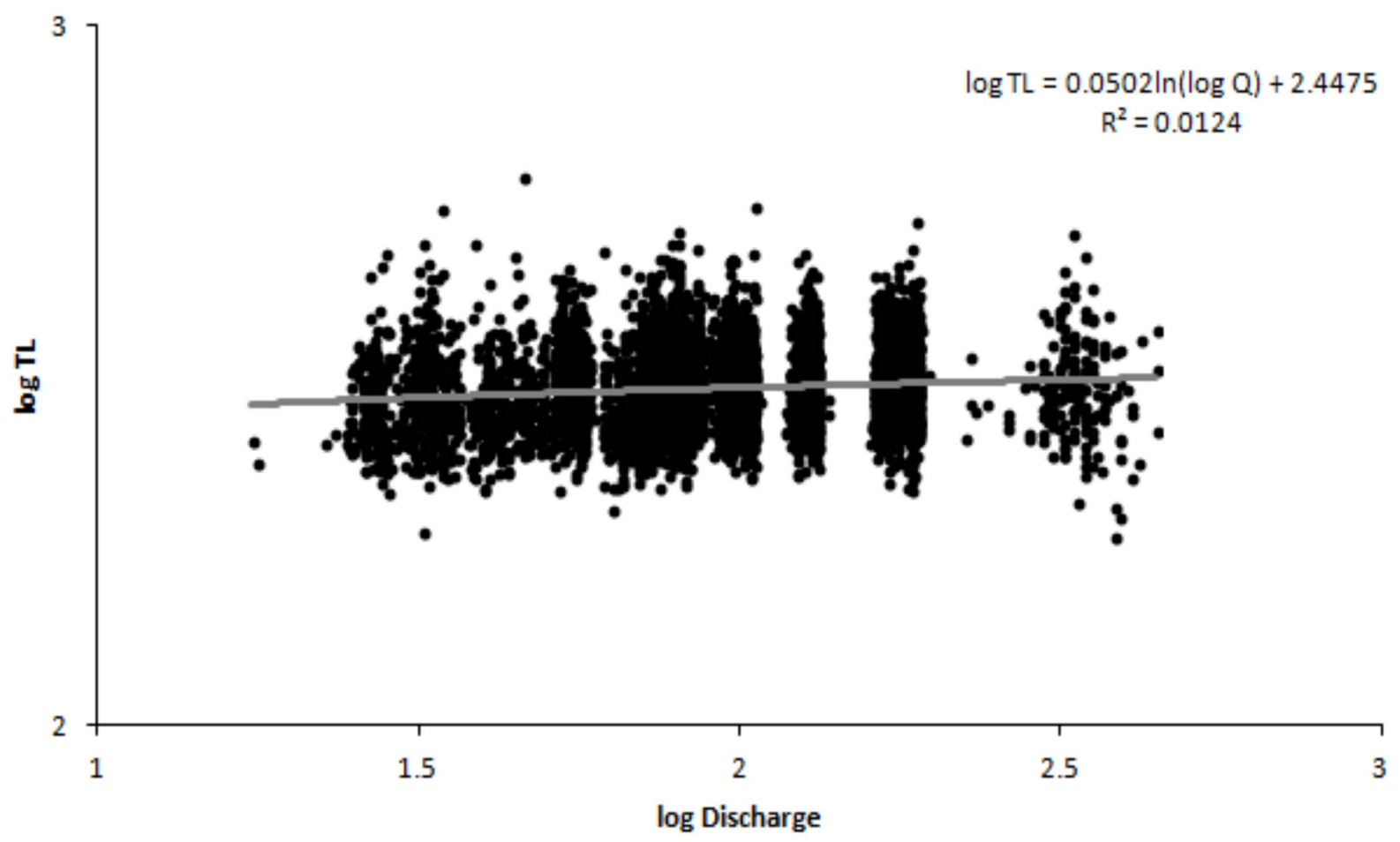

Figure 2.6. Relationship between log TL of American Eels passing through the eel ladder and log river discharge $\left(\mathrm{m}^{3} / \mathrm{s}\right)$ at the Millville Dam on the Shenandoah River.

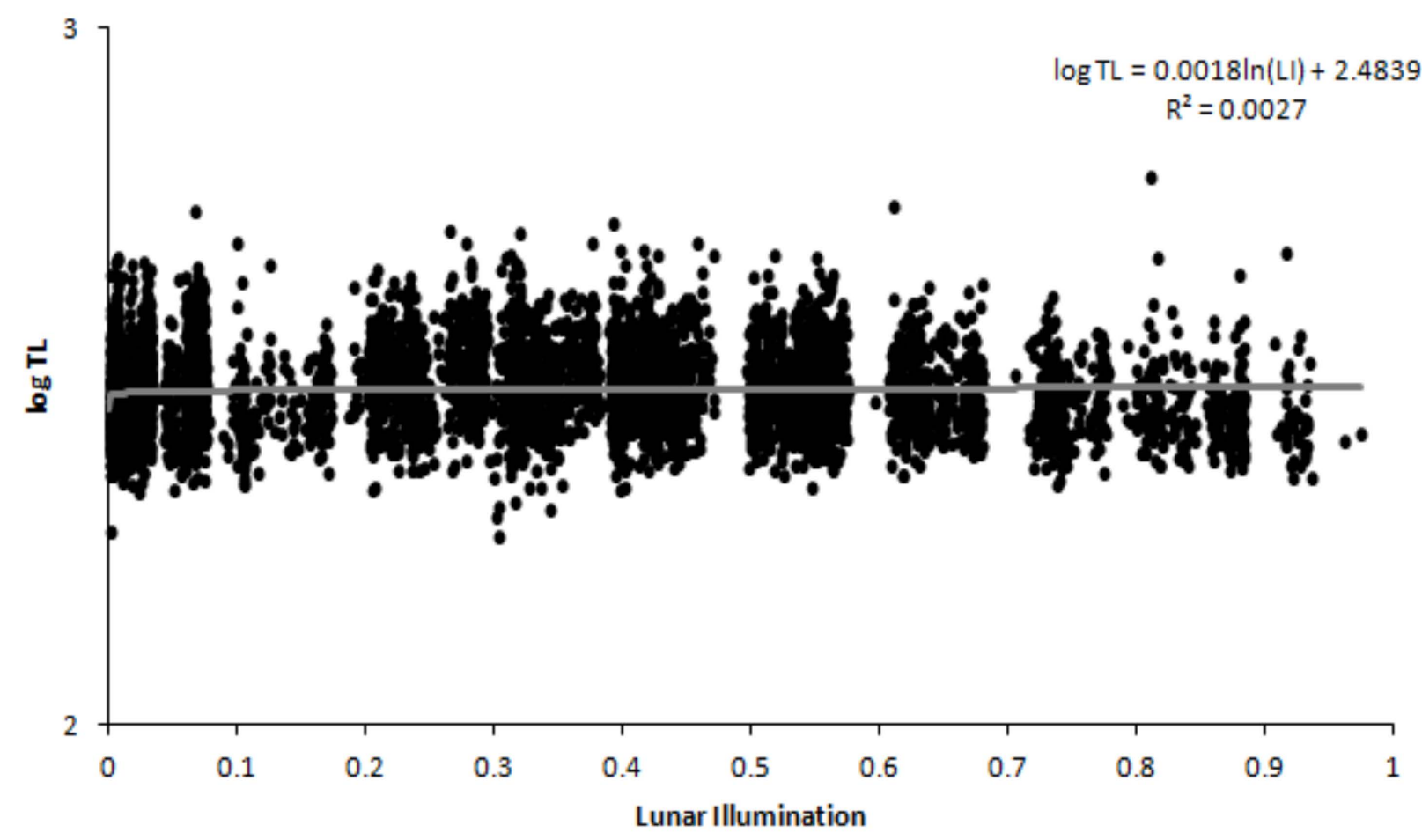

Figure 2.7. Relationship between $\log$ TL of American Eels passing through the eel ladder and lunar illumination at the Millville Dam on the Shenandoah River. 
Table 2.1. Model selection statistics (BIC values) for mixture models used to describe the number of modal peaks of American Eel passage at the Millville Dam eel ladder during periods of twilight and night. Models were fit to histograms of the number of individuals passing through the eel ladder pooled into a $14 \mathrm{~h}$ period (starting at 18:00 hours, with 10-min bins) for each multi-day passage event. The BIC values in bold print represent the best approximating model for each passage event.

BIC values for nine candidate models

\begin{tabular}{lcccccccccc} 
Passage event & Normal & 2-mixture & 3-mixture & 4-mixture & 5-mixture & 6-mixture & 7-mixture & 8-mixture & 9-mixture \\
\hline 17-28 May 2012 & 23159.8 & 22887.8 & 22781.1 & $\mathbf{2 2 7 5 4 . 5}$ & 22763.6 & 22770.6 & 22773.8 & 22780.4 & 22781.8 \\
12-21 July 2013 & 19863.9 & 19523.9 & 19391.6 & 19400.7 & 19404.6 & $\mathbf{1 9 3 8 4 . 6}$ & 19391.3 & 19388.8 & 19390.4 \\
22 July-3 Aug 2014 & 3379.1 & 3363.5 & $\mathbf{3 3 6 1 . 4}$ & 3364.9 & 3363.6 & 3369.3 & 3372.9 & 3378.2 & 3380.6 \\
13 Sept-1 Oct 2011 & 8610.2 & 8543.2 & 8528.0 & 8529.0 & 8532.0 & 8536.7 & 8536.3 & $\mathbf{8 5 2 5 . 0}$ & 8535.0 \\
18-27 Sept 2012 & 24388.0 & 23979.5 & 23871.8 & 23839.4 & 23800.4 & $\mathbf{2 3 7 9 6 . 5}$ & 23801.0 & 23798.8 & 23801.4 \\
14-21 Oct 2014 & 6656.9 & 6571.5 & 6577.3 & $\mathbf{6 5 6 3 . 2}$ & 6569.0 & 6574.6 & 6577.9 & 6585.9 & 6574.0 \\
\hline
\end{tabular}




\begin{tabular}{|c|c|c|c|c|c|c|c|c|c|}
\hline Model & k & $-2 \log (L)$ & $\mathrm{BIC}$ & $\Delta \mathrm{BIC}$ & Model & k & $-2 \log (L)$ & $\mathrm{BIC}$ & $\Delta \mathrm{BIC}$ \\
\hline \multicolumn{5}{|c|}{ 17-28 May 2012} & \multicolumn{5}{|c|}{ 12-21 July 2013} \\
\hline 4-mixture & 6 & 22709.4 & 22754.5 & 0 & 6-mixture & 8 & 19325.8 & 19384.6 & 0 \\
\hline 5-mixture & 7 & 22711 & 22763.6 & 9.2 & 8-mixture & 10 & 19315.2 & 19388.8 & 4.2 \\
\hline 6-mixture & 8 & 22710.4 & 22770.6 & 16.1 & 9-mixture & 11 & 19309.5 & 19390.4 & 5.8 \\
\hline 7-mixture & 9 & 22706.2 & 22773.8 & 19.4 & 7-mixture & 9 & 19325.1 & 19391.3 & 6.7 \\
\hline 8-mixture & 10 & 22705.2 & 22780.4 & 25.9 & 3-mixture & 5 & 19354.9 & 19391.6 & 7 \\
\hline 3-mixture & 5 & 22743.6 & 22781.1 & 26.7 & 4-mixture & 6 & 19356.6 & 19400.7 & 16.1 \\
\hline 9-mixture & 11 & 22699.1 & 22781.8 & 27.4 & 5-mixture & 7 & 19353.2 & 19404.6 & 20 \\
\hline 2-mixture & 4 & 22857.8 & 22887.8 & 133.4 & 2-mixture & 4 & 19494.5 & 19523.9 & 139.3 \\
\hline Normal & 3 & 23137.2 & 23159.8 & 405.3 & Normal & 3 & 19841.9 & 19863.9 & 479.3 \\
\hline \multicolumn{5}{|c|}{22 Jul-3 Aug 2014} & \multicolumn{5}{|c|}{13 Sept-1 Oct 2011} \\
\hline 3-mixture & 5 & 3333.2 & 3361.4 & 0 & 8-mixture & 10 & 8460.1 & 8525 & 0 \\
\hline 2-mixture & 4 & 3341 & 3363.5 & 2.1 & 3-mixture & 5 & 8495.5 & 8528 & 3 \\
\hline 5-mixture & 7 & 3324.1 & 3363.6 & 2.2 & 4-mixture & 6 & 8490.1 & 8529 & 4 \\
\hline 4-mixture & 6 & 3331.1 & 3364.9 & 3.6 & 5-mixture & 7 & 8486.5 & 8532 & 7 \\
\hline 6-mixture & 8 & 3324.2 & 3369.3 & 7.9 & 9-mixture & 11 & 8463.6 & 8535 & 10 \\
\hline 7-mixture & 9 & 3322.2 & 3372.9 & 11.5 & 7-mixture & 9 & 8477.9 & 8536.3 & 11.3 \\
\hline 8-mixture & 10 & 3321.9 & 3378.2 & 16.8 & 6-mixture & 8 & 8484.8 & 8536.7 & 11.7 \\
\hline Normal & 3 & 3362.2 & 3379.1 & 17.7 & 2-mixture & 4 & 8517.2 & 8543.2 & 18.2 \\
\hline 9-mixture & 11 & 3318.7 & 3380.6 & 19.3 & Normal & 3 & 8590.7 & 8610.2 & 85.2 \\
\hline \multicolumn{5}{|c|}{ 18-27 Sept 2012} & \multicolumn{5}{|c|}{ 14-21 Oct 2014} \\
\hline 6-mixture & 8 & 23736.2 & 23796.5 & 0 & 4-mixture & 6 & 6525.7 & 6563.2 & 0 \\
\hline 8-mixture & 10 & 23723.5 & 23798.8 & 2.3 & 5-mixture & 7 & 6525.2 & 6569 & 5.7 \\
\hline 5-mixture & 7 & 23747.6 & 23800.4 & 3.9 & 2-mixture & 4 & 6546.5 & 6571.5 & 8.3 \\
\hline 7-mixture & 9 & 23733.2 & 23801 & 4.5 & 9-mixture & 11 & 6505.2 & 6574 & 10.7 \\
\hline 9-mixture & 11 & 23718.6 & 23801.4 & 4.9 & 6-mixture & 8 & 6524.6 & 6574.6 & 11.4 \\
\hline 4-mixture & 6 & 23794.2 & 23839.4 & 42.9 & 3-mixture & 5 & 6546 & 6577.3 & 14.1 \\
\hline 3-mixture & 5 & 23834.2 & 23871.8 & 75.4 & 7-mixture & 9 & 6521.7 & 6577.9 & 14.7 \\
\hline 2-mixture & 4 & 23949.4 & 23979.5 & 183 & 8-mixture & 10 & 6523.4 & 6585.9 & 22.6 \\
\hline Normal & 3 & 24365.4 & 24388 & 591.6 & Normal & 3 & 6638.2 & 6656.9 & 93.7 \\
\hline
\end{tabular}

Appendix 2.1. Model selection statistics (model name, number of parameters (k), BIC and $\triangle B I C$ values) for mixture models used to describe the number of modal peaks of American Eel passage at the Millville Dam eel ladder during periods of twilight and night for each passage event. 